\title{
THE EFFECTS OF AGING
} ON DISSIMILAR METAL WELDED JOINTS WITH MULTIPASS WELDING OF HASTELLOY $X$ AND HASTELLOY W FILLER METAL

D. R. Ireland

July, 1966

REPORT

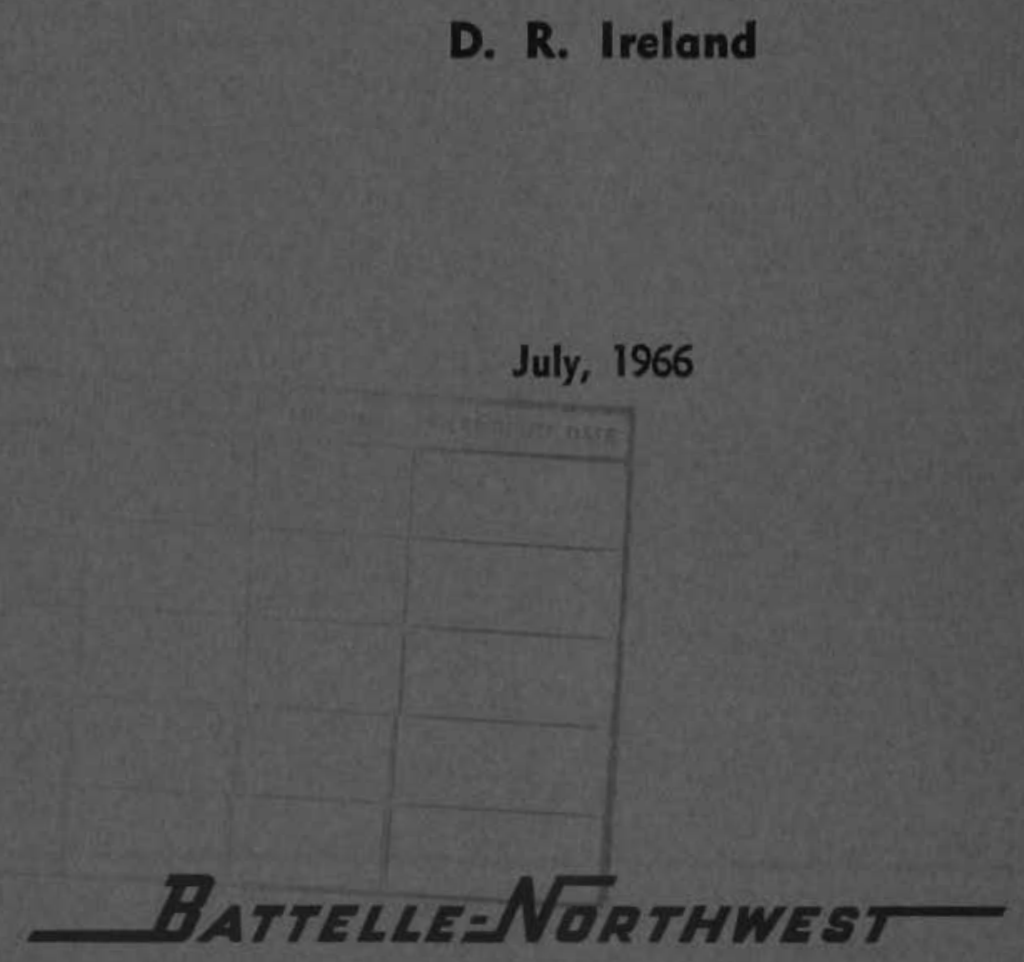

BATTELLE MEMORIAL INSTITUTE / PACIFIC NORTHWEST LABORATORY 


\section{LEGAL NOTICE}

This report was prepared as an account of Government sponsored work. Neither the United States, nor the Commission, nor any person acting on behalf of the Commission:

A. Makes any warranty or representation, expressed or implied, with respect to the accuracy, completeness, or usefulness of the information conlained in this report, or that the use of any information, apparatus, method, or process disclosed in this report may not infringe privately owned rights; or

B. Assumes any liabilities with respect to the use of, or for damages resulting from the use of any information, apparatus, method, or process disclosed in this report.

As used in the above, "person acting on behalf of the Commission" includes any employee or contractor of the Commission, or employee of such contractor, to the extent that such employee or contractor of the Commission, or employee of such contractor prepares, disseminates, or provides access to, any information pursuant to his employment or contract with the Commission, or his employment with such contractor.

\section{PACIFIC NORTHWEST LABORATORY \\ RICHLAND, WASHINGTON \\ operated by \\ BATTELLE MEMORIAL INSTITUTE}

for the

UNITED STATES ATOMIC ENERGY COMMISSION UNDER CONTRACT AT(45-1)-1830 


\author{
BNWL-290, Part I \\ UC-25, Metals, Ceramics \\ and Materials \\ (TID-4500)
}

\begin{abstract}
THE EFFECTS OF AGING
ON DISSIMILAR METAL WELDED JOINTS

WITH MULTIPASS WELDING OF HASTELLOY X

AND HASTELLOY W FILLER METAL

by

D. R. Ireland

Engineering Materials and Mechanics Section

Engineering Development Department
\end{abstract}

July, 1966

\author{
first UNRESTRICTED AUli $17^{\prime} 66$
DISTRIBUTION MADE \\ RICHLAND, WASHINGTON
}

PACIFIC NORTHWEST LABORATORY 


\section{THE EFFECTS OF AGING \\ ON DISSIMILAR METAL WELDED IOINTS \\ WITH MULTIPASS WELDING OF HASTELLOY X \\ AND HASTELLOY W FILLER METAL}

\section{INTRODUCTION}

A program was started to evaluate the age embrittlement of Hastelloy $\mathrm{X}$ and Hastelloy $\mathrm{W}$ weld metals in multipass-welded joints of Hastelloy X-280 to Haynes 25 and $316 \mathrm{SS}$. This program is evaluating the effects of aging for 500,1000 , and $5000 \mathrm{hr}$ at 1000, 1200, 1400, and $1600^{\circ} \mathrm{F}$ on the mechanical properties of Hastelloy X weld metal, Hastelloy W weld metal, Hastelloy $\mathrm{X}-280$ base metal and Haynes 25 base metal. This report describes the results of bend tests, tensile tests, hardness tests, and metallographic examinations of unaged material and material aged 500 and $1000 \mathrm{hr}$. The primary purpose of this investigation is to determine which of the two weld metals, Hastelloy $\mathrm{X}$ or Hastelloy $\mathrm{W}$, are best suited for prolonged exposure to temperatures of 1000 to $1600^{\circ} \mathrm{F}$. The ductiinties of the weld metals in multipass-welded joints of Hastelloy X-280 to 316 SS and Hastelloy X-280 to Haynes 25 were chosen for this investigation. The 316 SS is a well documented material and its properties are not evaluated in this study.

Bcth of these weld metals have been successfully used for joining dissimilar nickel-base alloys (1) Hastelloy W was specifically developed as a welding filler wire for use in joining dissimilar nickel-base alloys, nickelbase alloys to cobalt-base alloys, and nickel-base alloys to stainless steels. The two weld metals and the base metals evaluated in this program have previously been shown to suffer from age embrittlement when exposed to temperatures of 1200 to $1600^{\circ} \mathrm{F},(2-9)$

\section{SUMMARY AND CONCLUSIONS}

Within the limits of this investigation and on the basis of the information obtained to date, Hastelloy $W$ weld metal appears to be better suited to prolonged exposure to temperatures of 1000 to $1600^{\circ} \mathrm{F}$ than Hastelloy $\mathrm{X}$ weld metal. 
This conclusion is based on the test results of material aged 500 and $1000 \mathrm{hr}$ at $1000,1200,1400$, and $1600{ }^{\circ} \mathrm{F}$.

As expected, both weld metals age embrittle (lose ductility) with exposure to temperatures of 1000 to $1600{ }^{\circ} \mathrm{F}$. This age embrittlement of the weild metals goes through a cycle where the aging has its maximum effect on ductility and then overaging results in recovery of ductility.

Both weld metals reach similar minimum room temperature ductilities of approximately $2 \%$. The aging is more sluggish in Hastelloy $\mathrm{W}$ than in Hastelloy $X$. Hastelloy $W$ reaches its minimum room temperature ductility when aged $500 \mathrm{hr}$ at $1400^{\circ} \mathrm{F}$, while Hastelloy $\mathrm{X}$ reaches it when aged $500 \mathrm{hr}$ at $1200^{\circ} \mathrm{F}$.

The minimum elevated temperature ductilities of the two weld metals are quite different. Hastelloy $\mathrm{X}$ has a minimum ductility of $5 \%$ at $1200^{\circ} \mathrm{F}$, when aged $500 \mathrm{hr}$ at $1200{ }^{\circ} \mathrm{F}$; Hastelloy W has a minimum ductility of $10 \%$ at $1400{ }^{\circ} \mathrm{F}$, when aged $500 \mathrm{hr}$ at $1400{ }^{\circ} \mathrm{F}$.

The base metals, Hastelloy X-280 and Haynes 25, also age embrittle with exposure to temperatures of 1000 to $1600{ }^{\circ} \mathrm{F}$. Hastelloy X-280 reaches its minimum room temperature ductility of $12 \%$ when aged $500 \mathrm{hr}$ at $1600{ }^{\circ} \mathrm{F}$, and Haynes 25 reaches $6 \%$ when aged $1000 \mathrm{hr}$ at $1600{ }^{\circ} \mathrm{F}$. The elevated temperature ductilities of both weld metals are quite good, even in the aged conditions. Hastelloy X-280 maintains a ductility of $40 \%$ or more when aged and tested at all four aging temperatures, while Haynes 25 maintains a ductility of $18 \%$.

The aging of Hastelloy $\mathrm{X}$ weld metal and Hastelloy $\mathrm{X}-280$ base metal produces a carbide precipitate, probably a mixture of $\mathrm{M}_{23} \mathrm{C}_{6}$ and $\mathrm{M}_{6} \mathrm{C}$, in the grain boundaries. The aging of Hastelloy $\mathrm{W}$ weld metal at 1000 and $1200{ }^{\circ} \mathrm{F}$ creates a carbide precipitate similar to the one produced in Hastelloy $\mathrm{X}$ weld metal. Aging Hastelloy $\mathrm{W}$ at 1400 and $1600^{\circ} \mathrm{F}$ produces a Widmanstatten precipitate network of the beta and gamma phases of the nickel molybdenum binary diagram. Although Hastelloy $\mathrm{W}$ does have 5\% chromium that supresses the precipitatior. of the beta and gamma phases, the proionged aging of 500 and $1000 \mathrm{hr}$ does cause precipitation of these two phases. 
The most severe age embrittling temperatures are $1400^{\circ} \mathrm{F}$ for Hastelloy $\mathrm{W}$ weld metal and $1200{ }^{\circ} \mathrm{F}$ for Hastelloy $\mathrm{X}$ weld metal.

\section{BACKGROUND}

A brief summary of the physical metallurgy of Hastelloy $X$, Hastelloy $X-280$, Hastelloy $W$ and Haynes 25 should help in understanding the effects of aging on the structure of these metals. In general, these four superalloys are solid-solution strengthened alloys, but their excellent strength properties at temperatures above $1200^{\circ} \mathrm{F}$ depend on the combined effects of solid-solution strengthening, precipitation-hardening and dispersion hardening. Haynes 25 is a cobalt-base alloy, and the other three alloys are nickel-base alloys.

The plastic deformation of a metal depends on the movement of dislocations through a crystal lattice. Any mechanism that retards the dislocation movement $w i l l$ be a strengthening mechanism for the metal. Solid-solution strengthening is the result of lattice distortions caused by the solution of dissimilar elements in the crystal lattice. The maximum solid-solution strengthening is obtained when a large number of elements are dissolved to form an extremely complex solid solution. The se solid solutions unusually have a decreasing solubility of solute in solvent with decreasing temperature. This solvus line effect results in the precipitation of secondary phases at temperatures below the solution temperature.

The amount of secondary phase precipitated is dependent on the temperature, time at temperature, prior thermal mechanical treatment, and the particular alloying elements. The secondary phases of Hastelloy $\mathrm{X}$ and Hastelloy $\mathrm{X}-280$ are predominately the carbides $\mathrm{M}_{23} \mathrm{C}_{6}$ and $\mathrm{M}_{6} \mathrm{C}$.* Although the secondary phases of Hastelloy $\mathrm{W}$ are the carbides $\mathrm{M}_{23} \mathrm{C}_{6}$ and $\mathrm{M}_{6} \mathrm{C}$, they can also include the beta and gamma phases of the nickel molybdenum binary diagram. ${ }^{(6-10)}$ The principal precipitating second phase in Haynes 25 is a Laves phase. The chemical compositions of the materials studied in this investigation are listed in Table I.

*M represents metal or mixture of metals. 
TABLE I. Chemical Composition of Weld Specimen Materials

\begin{tabular}{|c|c|c|c|c|c|c|c|c|c|c|c|c|c|}
\hline \multirow[b]{2}{*}{ Material } & \multirow{2}{*}{$\begin{array}{l}\text { Condition } \\
\text { and Form } \\
\end{array}$} & \multicolumn{11}{|c|}{ Weight Percent } & \multirow[b]{2}{*}{$\overline{\mathrm{V}}$} \\
\hline & & $\mathrm{C}$ & $\overline{\mathrm{Mn}}$ & $\mathrm{P}$ & $\mathrm{S}$ & $\mathrm{Si}$ & $\mathrm{Cr}$ & $\mathrm{Ni}$ & $\mathrm{Co}$ & $\mathrm{Fe}$ & Mo & W & \\
\hline Hastelloy $\mathrm{X}$ & $\begin{array}{l}\text { as-drawn } \\
\text { welding wire }\end{array}$ & 0.07 & 0.52 & 0.018 & 0.009 & 0.88 & 21.57 & $\mathrm{Bal}$ & 1.22 & 18.09 & 9.05 & 0.66 & -- \\
\hline Hastelloy W & $\begin{array}{l}\text { as-drawn } \\
\text { welding wire }\end{array}$ & 0.02 & 0.59 & 0.012 & 0.013 & 0.42 & 4.86 & $\mathrm{Bal}$ & 0.56 & 6.00 & 23.96 & -- & 0.35 \\
\hline Hastelloy $\mathrm{X}-280$ & $\begin{array}{l}\text { solution } \\
\text { treated plate }\end{array}$ & 0.12 & 0.45 & 0.012 & 0.006 & 0.42 & 22 & $\mathrm{Bal}$ & 0.28 & 17.43 & 8.84 & 0.30 & \\
\hline Haynes 25 & $\begin{array}{l}\text { solution } \\
\text { treated plate }\end{array}$ & 0.07 & 1.39 & 0.012 & 0.009 & 0.59 & 19.76 & 10.19 & $\mathrm{Ba} 1$ & 1.80 & -- & 14.93 & $\cdots$ \\
\hline $\begin{array}{l}\text { AISI } 316 \\
\text { Stainless Steel }\end{array}$ & $\begin{array}{l}\text { annealed } \\
\text { plate }\end{array}$ & 0.08 & 2.00 & --- & --- & 1.00 & 17 & 12 & $\ldots$ & $\mathrm{Bal}$ & 2.5 & --- & --- \\
\hline
\end{tabular}

In most cases the carbides have a relatively minor effect on strength, but they can have a marked influence on the ultimate ductility. The effect of the carbides on the strength and ductility will depend on the location of the carbides and the rate of loading. The precipitation of $\mathrm{M}_{23} \mathrm{C}_{6}$ carbides in the grain boundaries of an alloy can increase the materials elongation at fracture in a creep-rupture test, and decrease the elongation at fracture in a tensile test; however, there is some disagreement as to what constitutes the correct positioning of the carbides. ${ }^{(3)}$ The preferred locations of these carbides depends on the prior thermalmechanical treatment of the materials.

A second complicating factor is the form the carbide takes during precipitation. The carbide $\mathrm{M}_{23} \mathrm{C}_{6}$ can precipitate as films, globules, platelets, lamellae, and a cellular growth. The least undesirable grain boundary precipitate form is globular because this form results in a shortening of the microcrack length. Because the $\mathrm{M}_{6} \mathrm{C}$ carbide is usually within the grains, it is associated with strengthening of the metal and is not generally considered a contributor to the embrittlement or loss in ductility of a metal. The principal constituent of the metallic radical in $\mathrm{M}_{23} \mathrm{C}_{6}$ is chromium; but nickel, cobalt, iron, molybdenum, and tungsten can substitute for chromium. The amount of substitution depends on the availability of the substituting elements and time at temperature. The principal constituents of the metallic radical in $\mathrm{M}_{6} \mathrm{C}$ are the heavy elements molybdenum and tungsten, although there is some solubility 
for chromium, nickel, and cobalt. Often $\mathrm{M}_{6} \mathrm{C}$ is found randomly distributed in the as-cast structure, and $\mathrm{M}_{23} \mathrm{C}_{6}$ is usually found in the grain boundaries. The beta and gamma phases in nickel-molybdenum alloys have been shown to be angular particles that tend to form Widmanstatten precipitate networks. (6) The addition of chromium to these alloys tends to suppress the formation of these beta and gamma phases. (10)

In Haynes 25 , the Laves phase has been identified as a hexagonal type structure with the probable formula of $(\mathrm{Co}, \mathrm{Ni}){ }_{2}(\mathrm{Cr}, \mathrm{W})$ and is usually referred to as $\mathrm{Co}_{2} \mathrm{~W}$. ${ }^{(2)}$ The preferred locations for this Laves phase in coldworked and annealed Haynes 25 plate would be in the grains and on the twin planes. The Laves phase $\mathrm{Co}_{2} \mathrm{~W}$ is the principal embrittling agent in Haynes 25 .

\section{TEST RESULTS*}

\section{BEND TESTS}

The room temperature bend test results are graphically represented in Figure 1 and listed in Table II. In all cases, the failure of a bend specimen

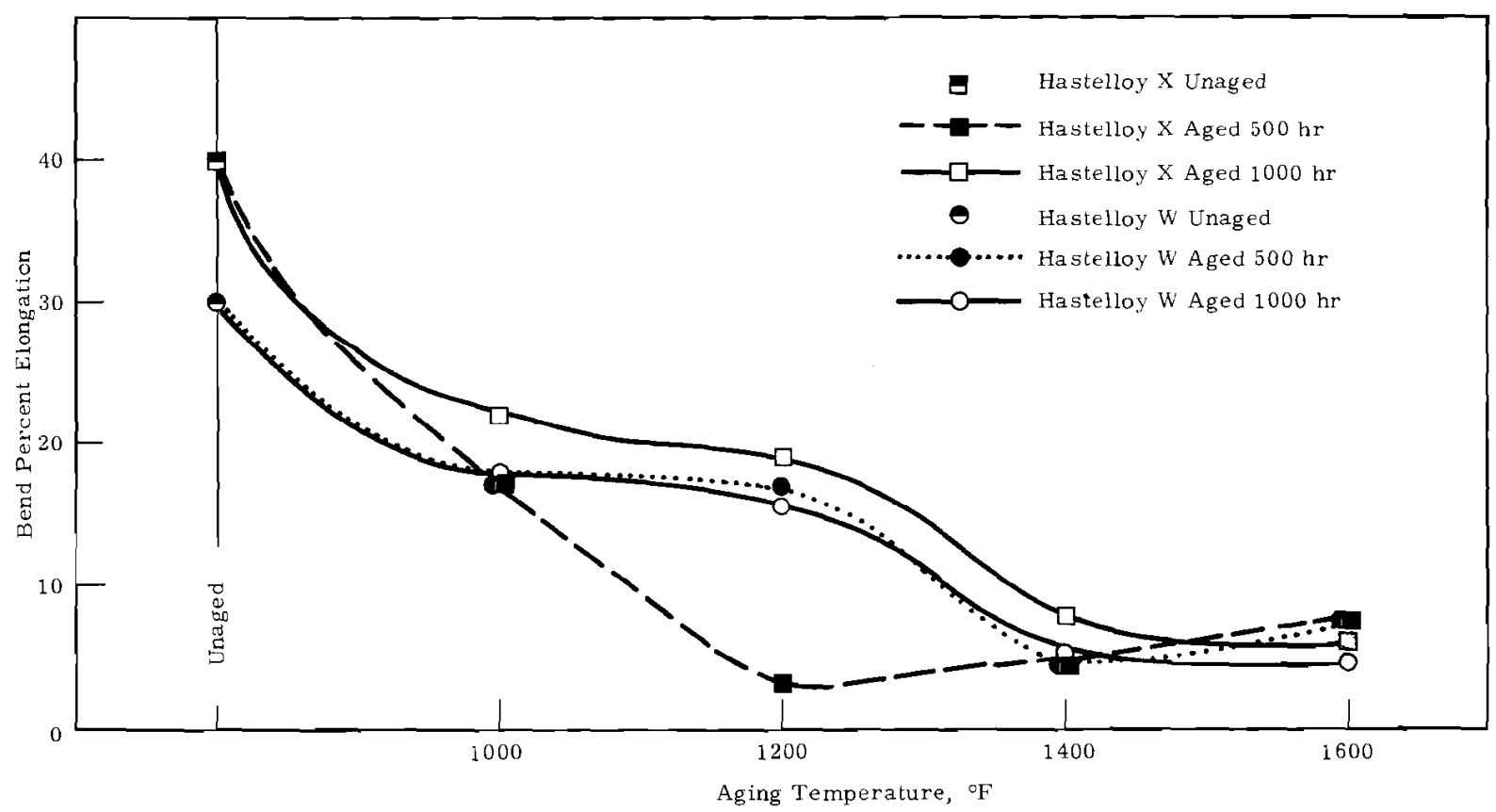

FIGURE 1. The Maximum Elongation in the Outer Fibers of Unaged and Aged Weld Specimens, Bent to Failure in a Longitudinal-Weld Bend Test

* The test specimens and procedures are described in the experimental procedures section of this report. 
originated in the weld metal. Therefore, the bend test results represent the room temperature outer fiber maximum elongation of Hastelloy $\mathrm{X}$ and Fiastellcy W weld metals.

TABLE ii. Rcom Temperature Bend Ductility of Dissimilar Metal Welded Joints, Wh Hastelloy X and Hastelloy W Weld Metal

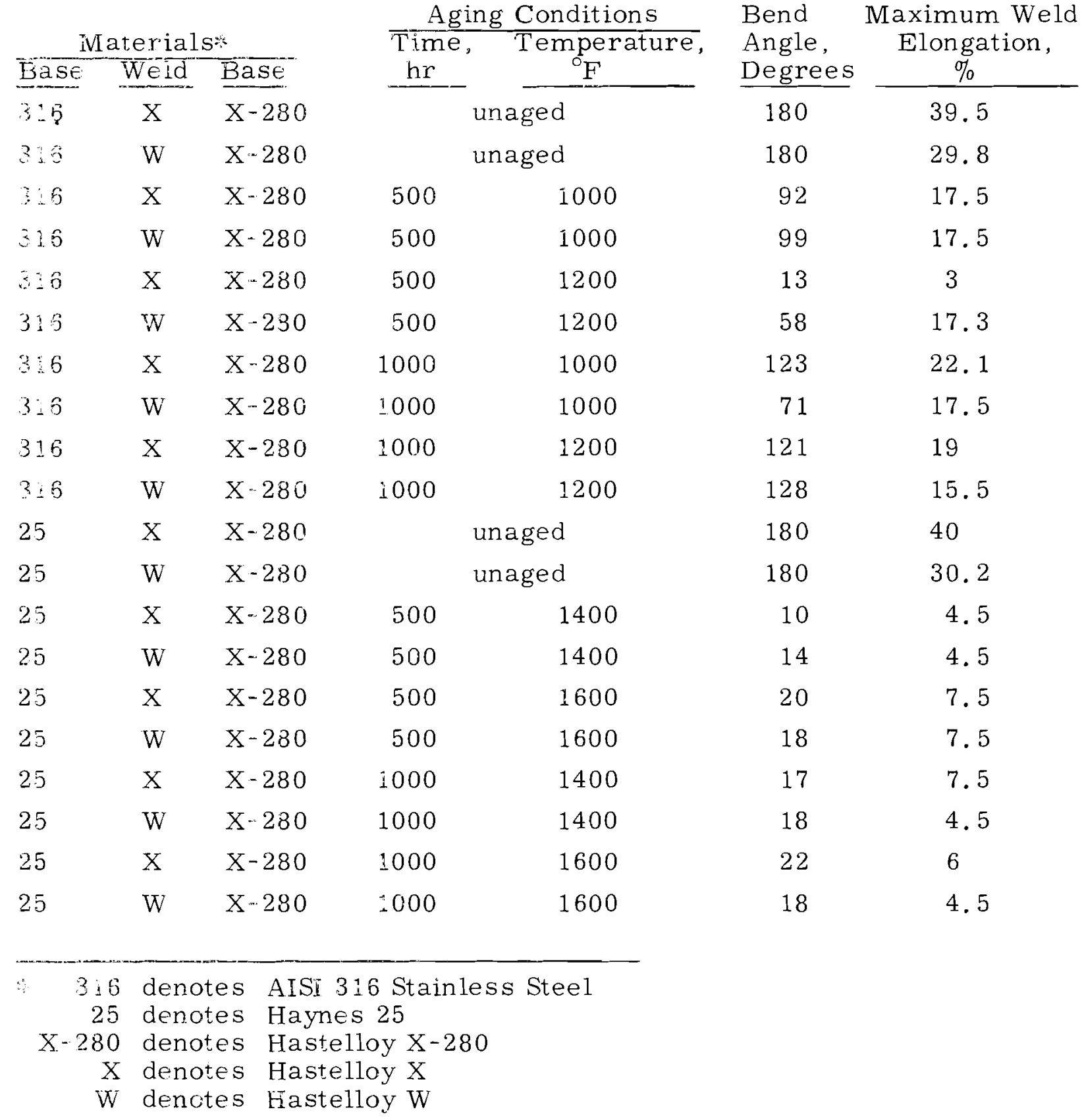


Three typical bend specimen failures of high, moderate and low ductilities are shown in Figures 2, 3, and 4. Joints of 316 SS to Hastelloy $\mathrm{X}-280$ that failed with low ductility differed from the example shown in Figure 4. Due to the high fracture toughness of 316 SS the crack originating in the weld metal did not significantly penetrate the 316 SS base metal. However, the appearance and behavior of the crack in the weld metal and Hastelloy X-280 base metal of these low ductility 316 SS joints was the same as for the low ductility joints of Hastelloy X-280 to Haynes 25. The macro- and microfracture appearances of a typical low ductility failure are shown in Figure 5. There was no apparent difference in the fracture appearance of Hastelloy X and Hastelloy $\mathrm{W}$ weld metals in the se bend tests. The bend specimen failure shown in Figure 5 represents intergranular fracture in the weld metal and both base metals. When the low ductility bend specimens failed, the first appearance of a crack on the tension surface of the specimen was nearly coincident with complete fracture of the base metal and weld metal.

Both weld metals suffered a loss in room temperature ductility with aging. Although the aging is more sluggish in Hastelloy W than in Hastelloy $X$, both weld metals reached similar minimum ductilities of 3 to $5 \%$. The only significant differences in room temperature bend ductility of the weld metals is for the uriaged condition and the $500 \mathrm{hr}$ age at $1200^{\circ} \mathrm{F}$ condition. The unaged bend specimens indicate that Hastelloy $X$ is more ductile than Hastelloy W。Aging at $1200^{\circ} \mathrm{F}$ does not significantly affect the ductility of Hastelloy W, but it drastically affects the ductility of Hastelloy X. Hastelloy $\mathrm{X}$ reaches its minimum bend ductility when aged at $120{ }^{\circ} \mathrm{F}$ for $500 \mathrm{hr}$ : aging for $1000 \mathrm{hr}$ at $1200^{\circ} \mathrm{F}$ causes overaging which results in an increase in bend ductility. Hastelloy $\mathrm{W}$ reaches its minimum bend ductility when aged $500 \mathrm{hr}$ at $1400^{\circ} \mathrm{F}$, and when aged $1000 \mathrm{hr}$ at $1600{ }^{\circ} \mathrm{F}$ 。 TENSILE TESTS

Uniaxial tensile tests of aged and unaged Hastelloy $\mathrm{X}$ weld metal, Hastelloy W weld metal, Hastelloy X-280 base metal and Haynes 25 base metal were run at room temperature and at the aging temperatures of 1000 , 1200,1400 , and $1600^{\circ} \mathrm{F}$. The results of these tests on the weld metals and base metals are listed in Tables III and IV, respectively. 


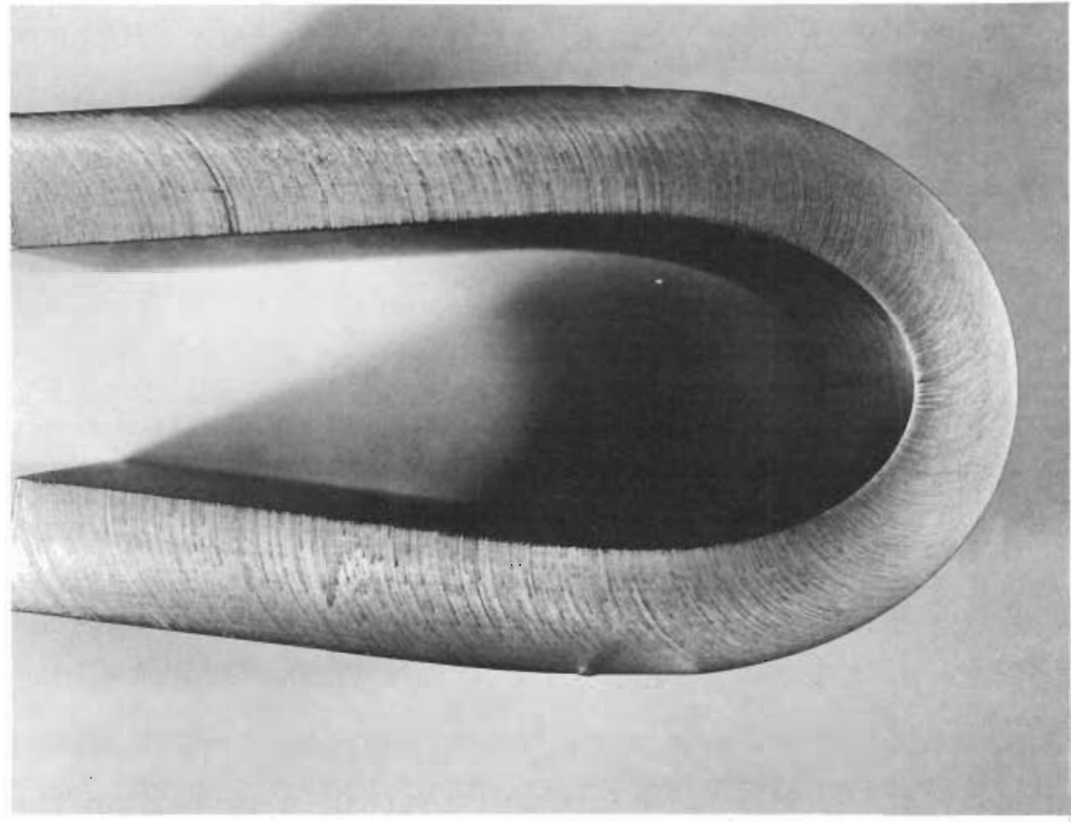

Side View

$\frac{7}{8} \mathrm{X}$

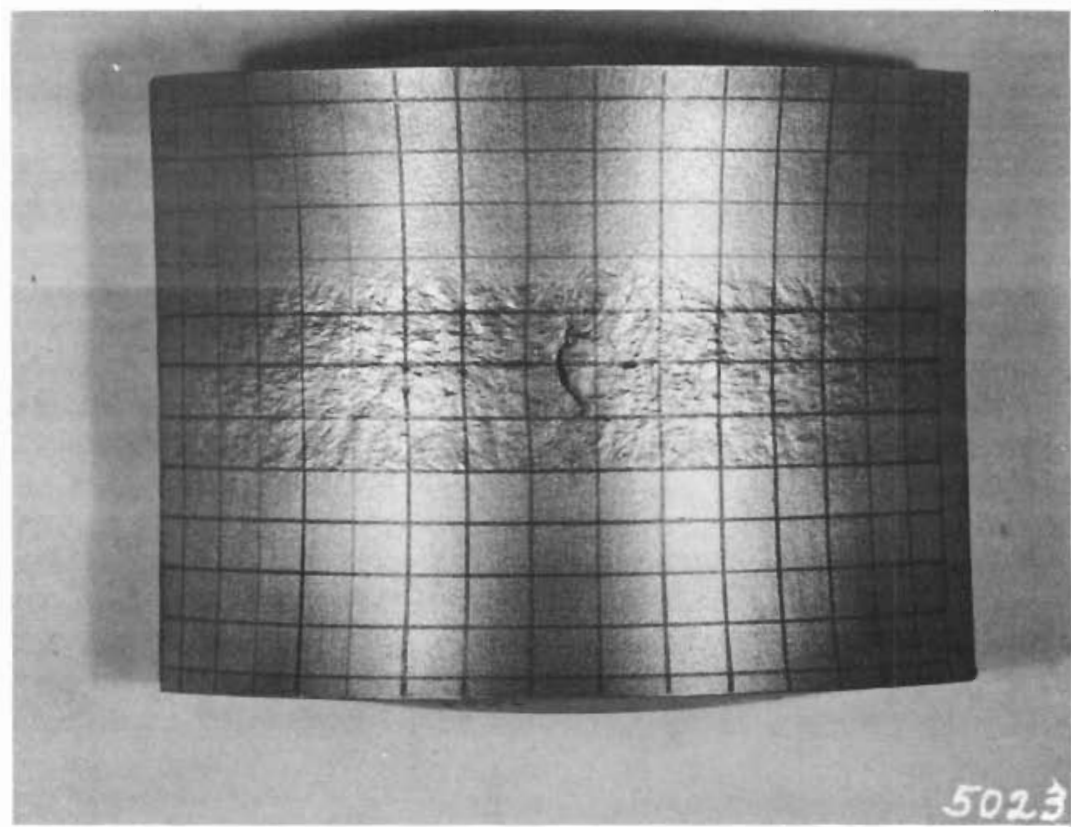

Face View $\frac{7}{8} \mathrm{X}$

FIGURE 2. Typical Unaged Bend Specimen Failure, High Ductility 


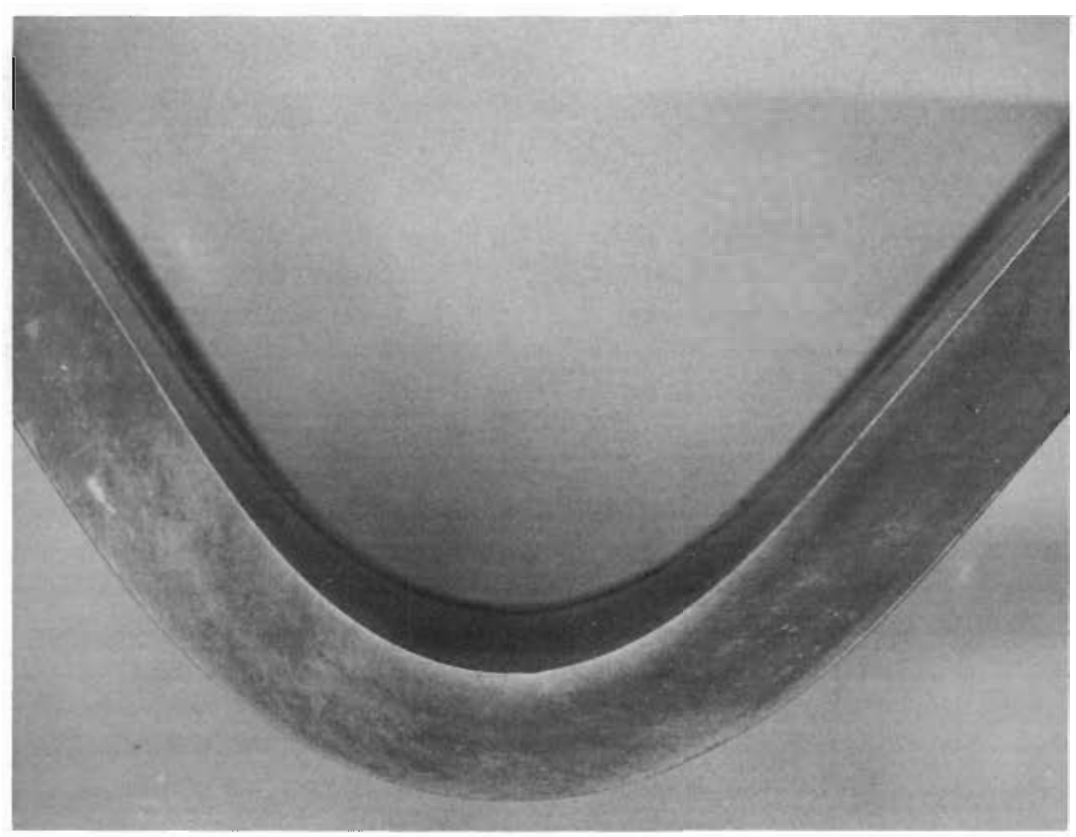

Side View

$\frac{7}{8} \mathrm{X}$

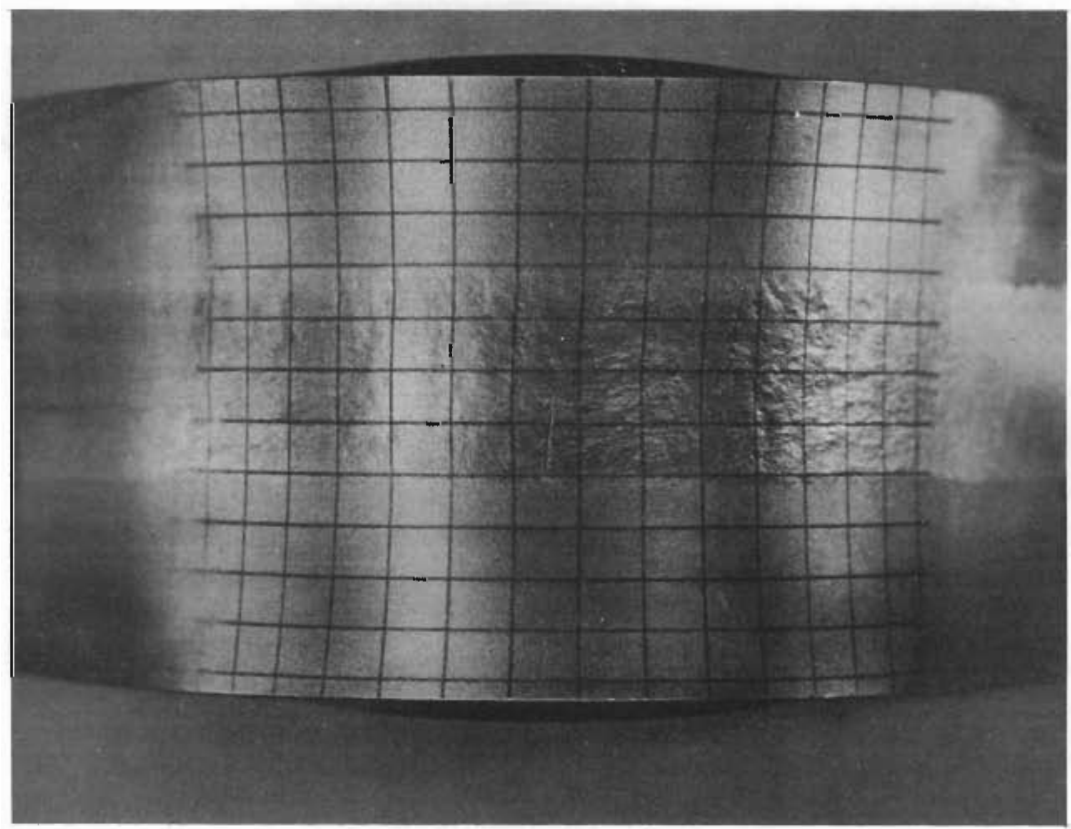

Face View

$\frac{7}{8} \mathrm{X}$

FIGURE 3. Typical Aged Bend Specimen Failure, Moderate Ductility 


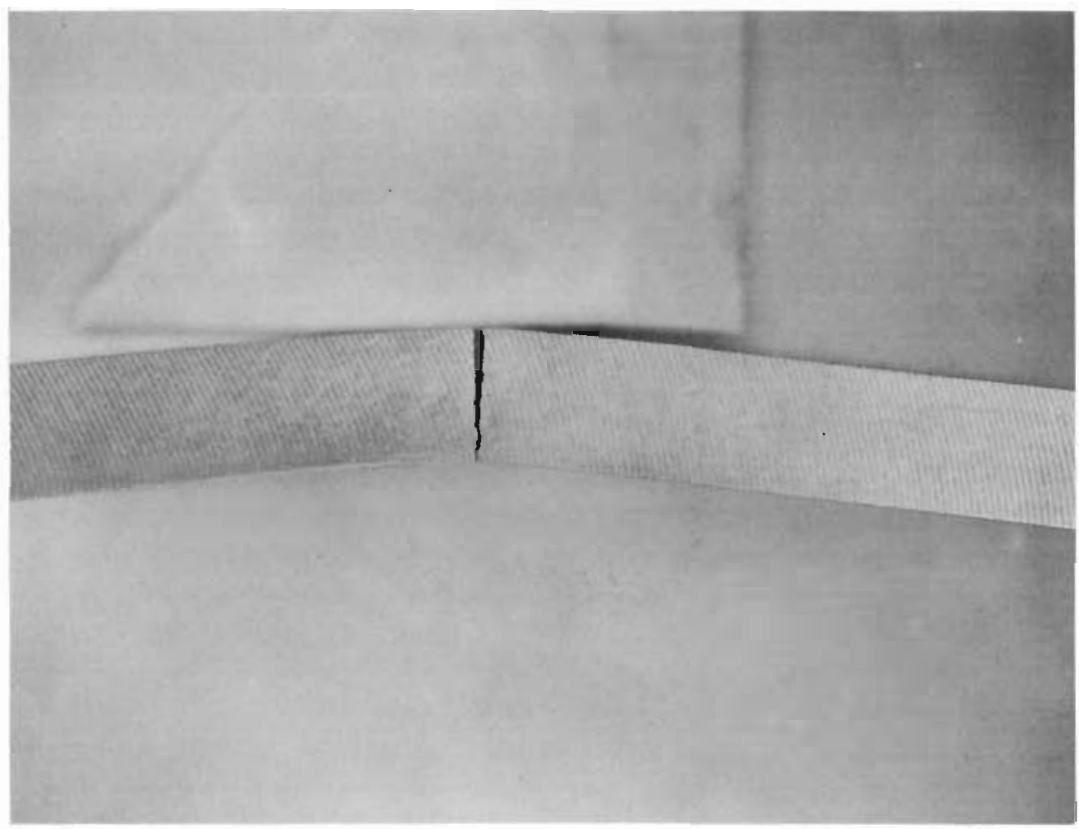

Side View $\frac{7}{8} \mathrm{X}$

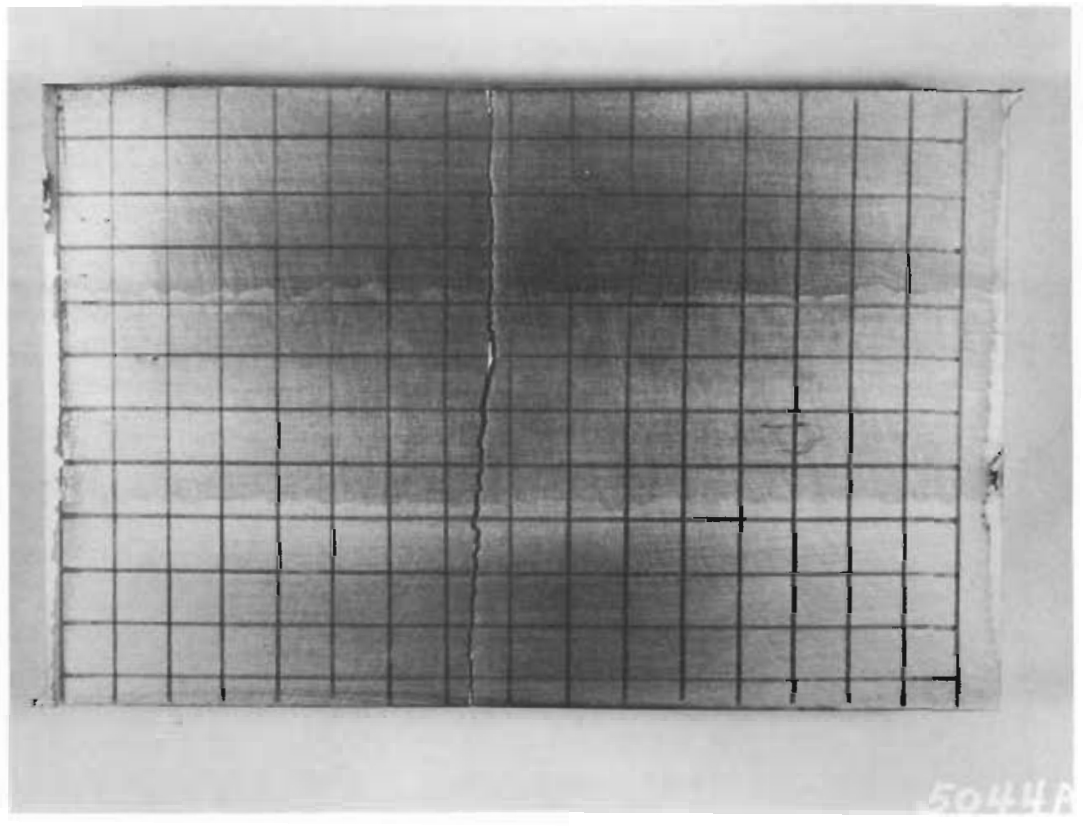




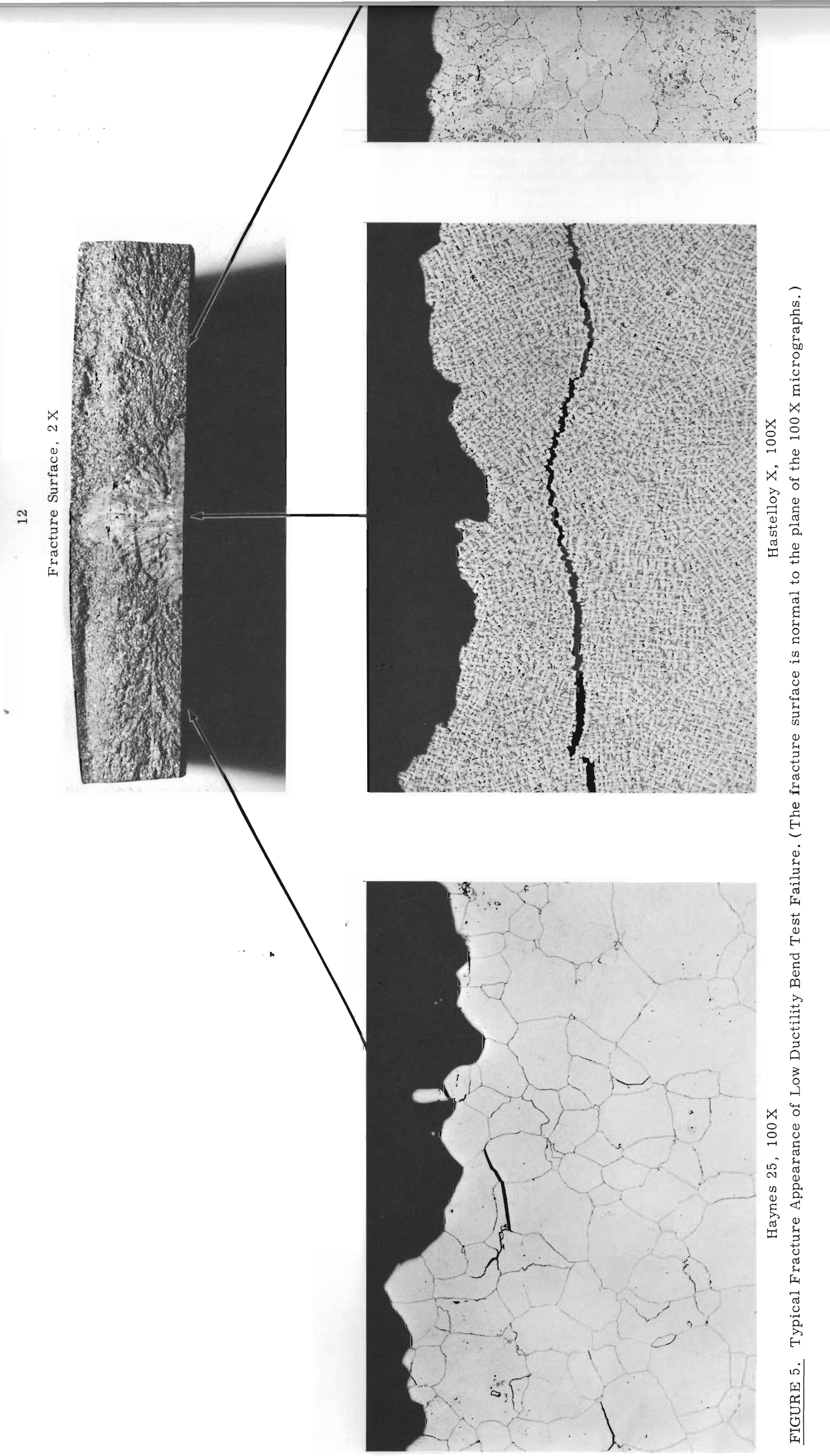



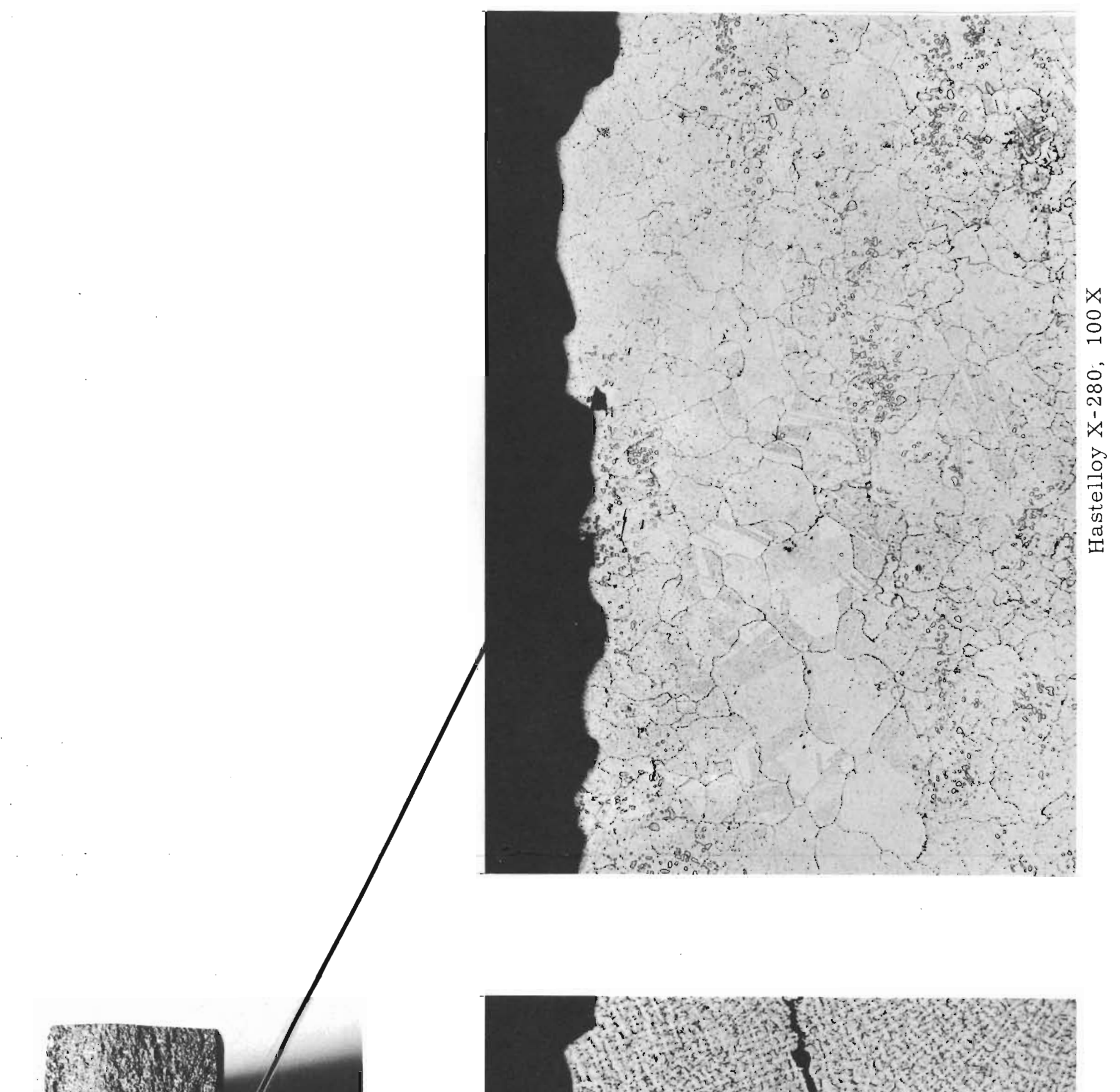
1. W. a. 2. 3 y. 2. $4 \times$ 2. $2^{2} \times 1$ L

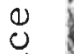
$(2,5, x+4)$

ษ के

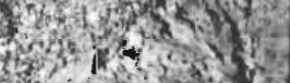
岁 2 ton 0 1,1015 t.. 056 ? 4. 617 . 2. 310 (.) $x$ ) 1. $1+1$ 36 - $317 \mathrm{~m}$ . 17.92

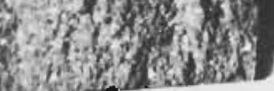

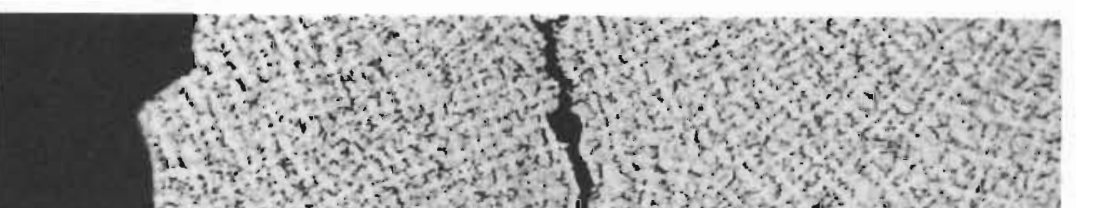

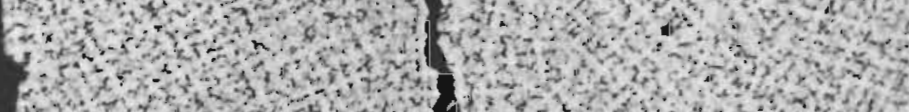

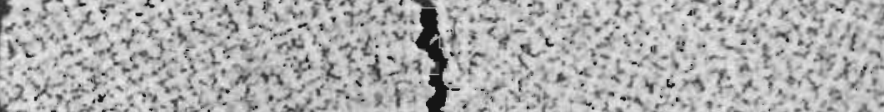

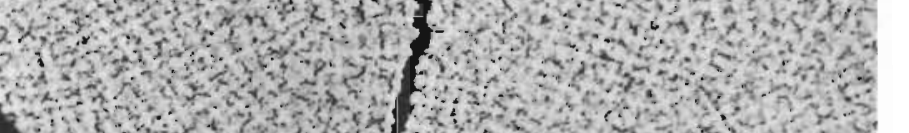

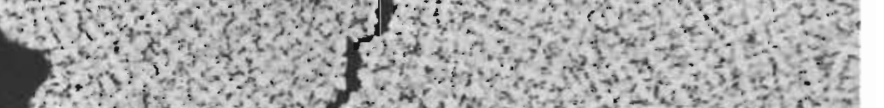

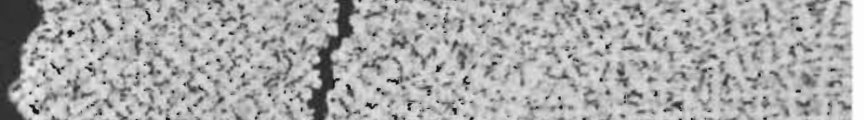

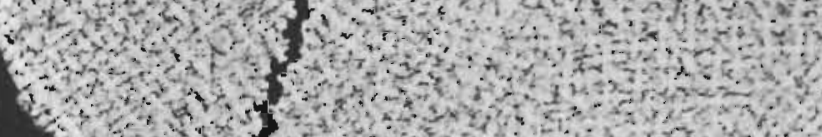

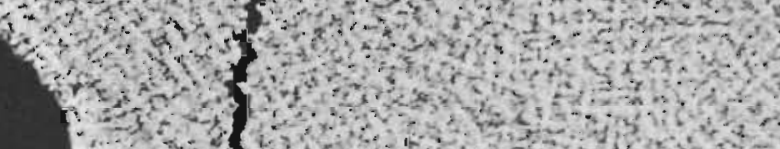

용

$-\frac{0}{ \pm}$

出

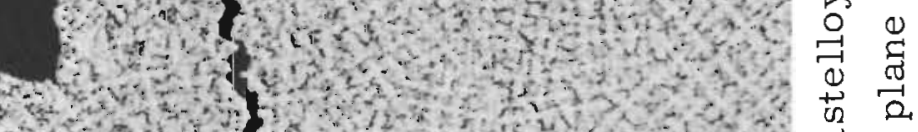
1 mank

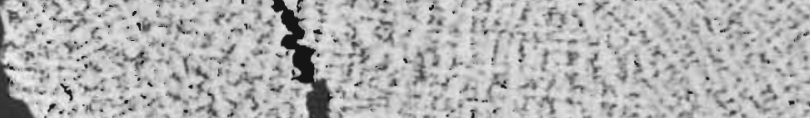
Why In b onthin Wrot $n$ 
TA BLE III. Mechanical Properties of Hastelloy X and Hastelloy W Weld Metal

\begin{tabular}{|c|c|c|c|c|c|c|}
\hline \multirow{2}{*}{\multicolumn{2}{|c|}{ Aging Conditions }} & \multirow{3}{*}{ Material $^{(a)}$} & \multirow{3}{*}{$\begin{array}{c}\text { Test } \\
\text { Temperature, } \\
{ }^{\circ} \mathrm{F} \\
\end{array}$} & \multicolumn{2}{|c|}{ Strength $10^{3} \mathrm{psi}$} & \multirow{3}{*}{$\begin{array}{c}\text { Total } \\
\text { Elongation } \\
\% \\
\end{array}$} \\
\hline & & & & & Ultimate & \\
\hline $\begin{array}{l}\text { Time, } \\
\text { hr } \\
\end{array}$ & 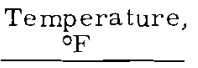 & & & $\begin{array}{l}\text { Yield* } \\
\text { Strength }\end{array}$ & $\begin{array}{l}\text { Tensile } \\
\text { Strength }\end{array}$ & \\
\hline \multicolumn{2}{|c|}{ unaged } & $x$ & Room & 57.2 & 82.3 & 11.3 \\
\hline \multicolumn{2}{|c|}{ unaged } & W & Room & 64.8 & 113.5 & 32.2 \\
\hline \multicolumn{2}{|c|}{ unaged } & $\mathrm{x}$ & 1000 & 45.9 & 69.4 & 24.9 \\
\hline \multicolumn{2}{|c|}{ unaged } & W & 1000 & 50.4 & 88.5 & 26.2 \\
\hline \multicolumn{2}{|c|}{ unaged } & $\mathrm{X}$ & 1200 & 40.8 & 72.9 & 29.9 \\
\hline \multicolumn{2}{|c|}{ unaged } & W & 1200 & 48.8 & 81.1 & 28.4 \\
\hline \multicolumn{2}{|c|}{ unaged } & $\mathrm{x}$ & 1400 & 38.3 & 53.2 & 32.7 \\
\hline \multicolumn{2}{|c|}{ unaged } & $\mathrm{W}$ & 1400 & 43.4 & $6 \% .7$ & 15.8 \\
\hline \multicolumn{2}{|c|}{ unaged } & $x$ & 1600 & 24.9 & 32.3 & 29.1 \\
\hline \multicolumn{2}{|c|}{ unaged } & W & 1600 & 32.8 & 48.3 & 16.8 \\
\hline 500 & 1000 & $x$ & Room & 59.5 & 108.5 & 23.9 \\
\hline 500 & 1000 & $\mathrm{~W}$ & Room & 89.3 & 145.3 & 17.8 \\
\hline 500 & 1000 & $\mathrm{x}$ & 1000 & 46.8 & 73.9 & 15.7 \\
\hline 500 & 1000 & W & 1000 & 76.4 & 118.4 & 17.6 \\
\hline 500 & 1200 & $x$ & Room & 84.6 & 114.5 & 1.5 \\
\hline 500 & 1200 & $\mathrm{~W}$ & Room & 78.6 & 142.4 & 12.3 \\
\hline 500 & 1200 & $\mathrm{x}$ & 1200 & 62.3 & 87.1 & 5.2 \\
\hline 500 & 1200 & $\mathrm{~W}$ & 1200 & 67.1 & 108.2 & 12.7 \\
\hline 500 & 1400 & $\mathrm{x}$ & Room & 77.1 & 126.3 & 3.7 \\
\hline 500 & 1400 & W & Room & 91.7 & 143.7 & 2.1 \\
\hline 500 & 1400 & $\mathrm{x}$ & 1400 & 42.3 & 60.5 & 18.1 \\
\hline 500 & 1400 & $\mathrm{~W}$ & 1400 & 59.8 & 88.4 & 9.6 \\
\hline 500 & 1600 & $\mathrm{x}$ & Room & 59 & 106.9 & 4.9 \\
\hline 500 & 1600 & W & Room & 75.6 & 138.4 & 5.0 \\
\hline 500 & 1600 & $\mathrm{x}$ & 1600 & 21.8 & 35.5 & 36.1 \\
\hline 500 & 1600 & W & 1600 & 27 & 43.3 & 19.1 \\
\hline 1000 & 1000 & $x$ & Room & 63 & 85.3 & 3.5 \\
\hline 1000 & 1000 & W & Room & 89.8 & 147.3 & 18.1 \\
\hline 1000 & 1000 & $x$ & 1000 & 48.1 & 87.4 & 17.1 \\
\hline 1000 & 1000 & W & 1000 & 78.6 & 124.9 & 18.0 \\
\hline 1000 & 1200 & $x$ & Room & 46.3 & 78.6 & 8.1 \\
\hline 1000 & 1200 & $\mathrm{~W}$ & Room & 67 & 105 & 11.3 \\
\hline 1000 & 1200 & $x$ & 1200 & 31.3 & 65.9 & 15.8 \\
\hline 1000 & 1200 & $\mathrm{~W}$ & 1200 & 47.3 & 95.3 & 23.4 \\
\hline 1000 & 1400 & $\mathrm{X}$ & Room & 64.4 & 131 & 7.7 \\
\hline 1000 & 1400 & $\mathrm{~W}$ & Room & 83.2 & 149.8 & 3.7 \\
\hline 1000 & 1400 & $x$ & 1400 & 43.4 & 66.6 & 32.4 \\
\hline 1000 & 1400 & W & 1400 & 28.1 & 92.2 & 10.0 \\
\hline 1000 & 1600 & $\mathrm{x}$ & Room & 53.9 & 113.8 & 6.2 \\
\hline 1000 & 1600 & $\mathrm{~W}$ & Room & 71.8 & 139.6 & 5.1 \\
\hline 1000 & 1600 & $\mathrm{x}$ & 2600 & 24.3 & 37.5 & 43.6 \\
\hline 1000 & 1600 & W & 1600 & 29.9 & 47.2 & 29.6 \\
\hline
\end{tabular}

"This is the $0.2 \%$ off set yield strength.

(a) $\mathrm{X}$ denotes Hastelloy $\mathrm{X}$

W denotes Hastelloy W 
TABLE IV. Mechanical Properties of Hastelloy X-280 and Haynes 25 Base Metal

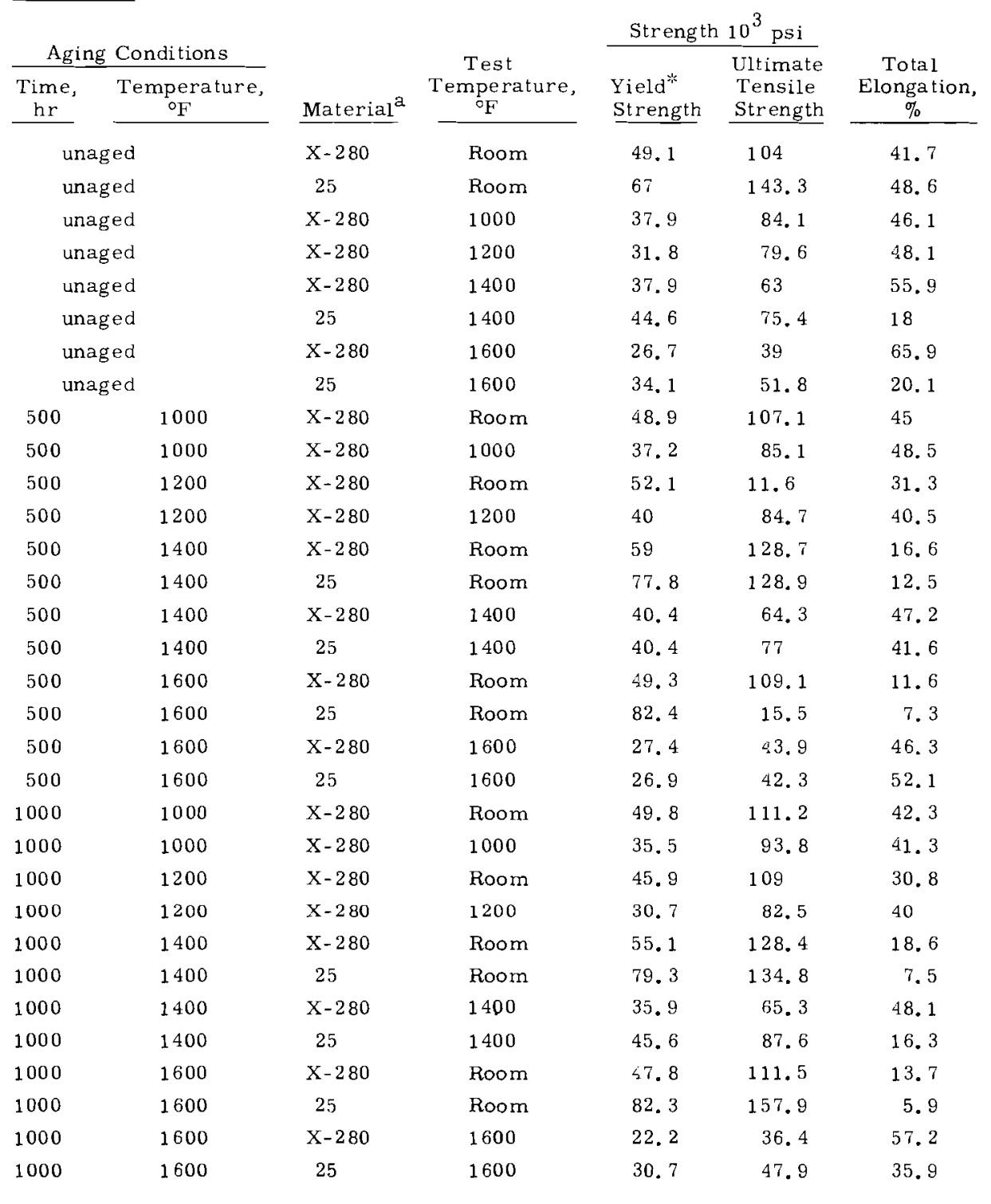

*This is the $0.2 \%$ off set yield strength.

${ }^{a} \mathrm{X}-280$ denotes Hastelloy $\mathrm{X}-280$

25 denotes Haynes 25 
The influence of aging at temperatures between 1000 and $1600^{\circ} \mathrm{F}$ on the room temperature mechanical properties of the weld metals is shown in Figure 6. These tensile tests indicate that although the unaged weld metals have nearly the same yield strength, Hastelloy $W$ is considerably more ductile than Hastelloy $X$. Aging Hastelloy $X$ at $1000^{\circ} \mathrm{F}$ for $500 \mathrm{hr}$ significantly improves its ductility and does not appreciably change its yield strength. Additional aging of Hastelloy $\mathrm{X}$ for $1000 \mathrm{hr}$ at $1000^{\circ} \mathrm{F}$ results in a significant loss in ductility to a low of $3.5 \%$, and aging does not appreciably change the yield strength. Hastelloy $\mathrm{W}$ aged at $1000^{\circ} \mathrm{F}$ indicates very little difference in the room temperature mechanical properties for material aged for 500 and $1000 \mathrm{hr}$. This aging of Hastelloy $\mathrm{W}$ does increase its yield strength to 89,000 psi and lowers its ductility to nearly $18 \%$.

Aging the two weld metals for $500 \mathrm{hr}$ at $1200^{\circ} \mathrm{F}$ raises their yield strengths to approximately $80,000 \mathrm{psi}$, and it reduces the ductility of Hastelloy $\mathrm{X}$ to $1.5 \%$ and the ductility of Hastelloy $\mathrm{W}$ to $12 \%$. Additional aging of Hastelloy $X$ at $1200{ }^{\circ} \mathrm{F}$ results in overaging, with the $1000 \mathrm{hr}$ age causing an improvement of ductility to $8 \%$ and a decrease in yield strength to 46,000 psi. Additional aging of Hastelloy $W$ at $1200^{\circ} \mathrm{F}$ did not appreciably affect the ductility but lowered the yield strength to $67,000 \mathrm{psi}$.

Aging Hastelloy $\mathrm{X}$ for $500 \mathrm{hr}$ at $1400^{\circ} \mathrm{F}$ lowered its ductility to $4 \%$ and raised its yield strength to 77,000 psi. Additional aging of Hastelloy $\mathrm{X}$ at this temperature results in overaging, an increase in ductility io $8 \%$, and a decrease in yield strength to 54,000 psi. Similar aging of Hastellcy W at $1400{ }^{\circ} \mathrm{F}$ results in a decrease in ductility to $2 \%$ and an increase in yield strength to 92,000 psi. Additional aging of Hastelloy $\mathrm{W}$ at this temperature does not appreciably affect its room temperature ductility but slightly lowers the yield strength which indicates overaging is beginning to occur.

Both of the weld metals aged at $1600^{\circ} \mathrm{F}$ for 500 and $1000 \mathrm{hr}$ have room temperature ductilities of approximately $5 \%$. Hastelloy X aged at $1600^{\circ} \mathrm{F}$ for 500 and $1000 \mathrm{hr}$ has yield strengths of 59,000 and 54,000 psi, respectively. The room temperature tensile test data indicate that both metals reach similar minimum ductilities for a given maximum embrittleness. The data also indicate that Hastelloy $X$ reaches its minimum ductility much faster than does Hastelloy W. 


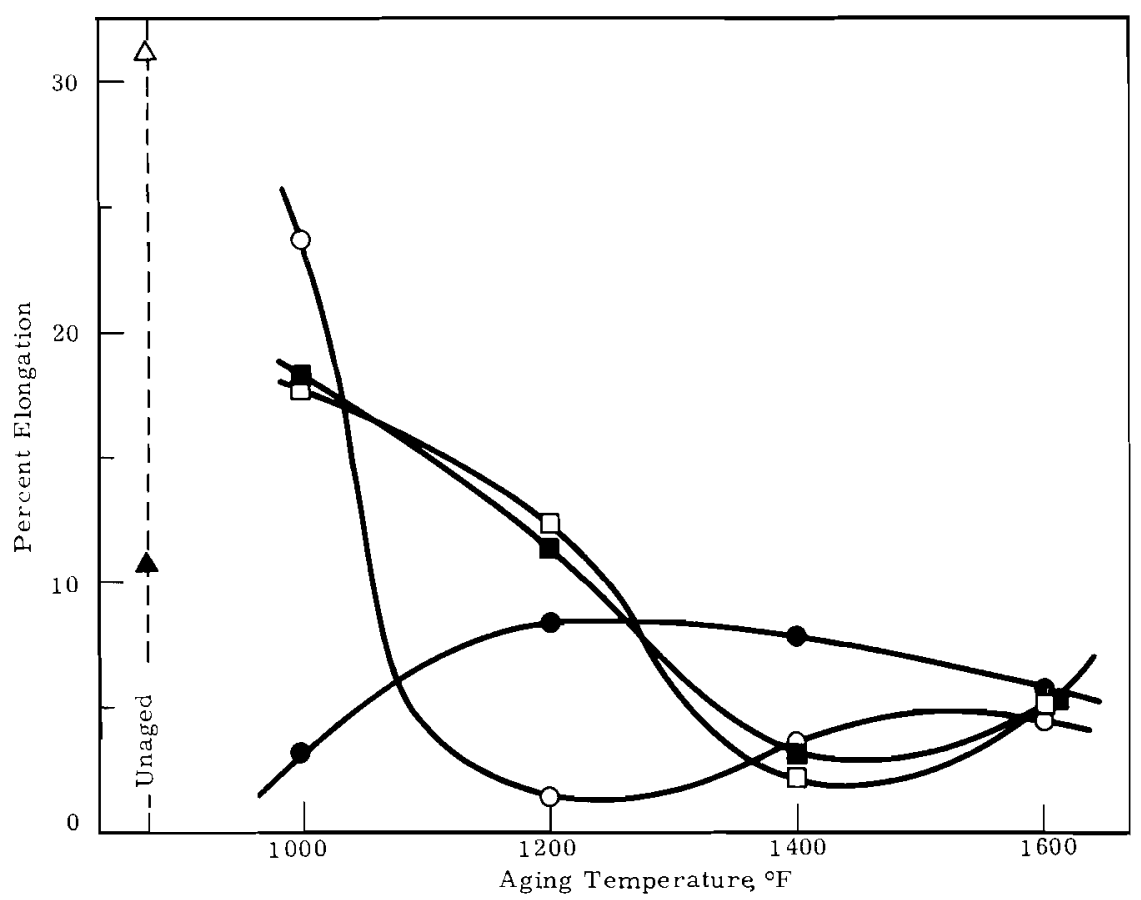

$\square 500 \mathrm{hr}$ Hastelloy W

O 500 hr Hastelloy $\mathrm{X}$

口 $1000 \mathrm{hr}$ Hastelloy W

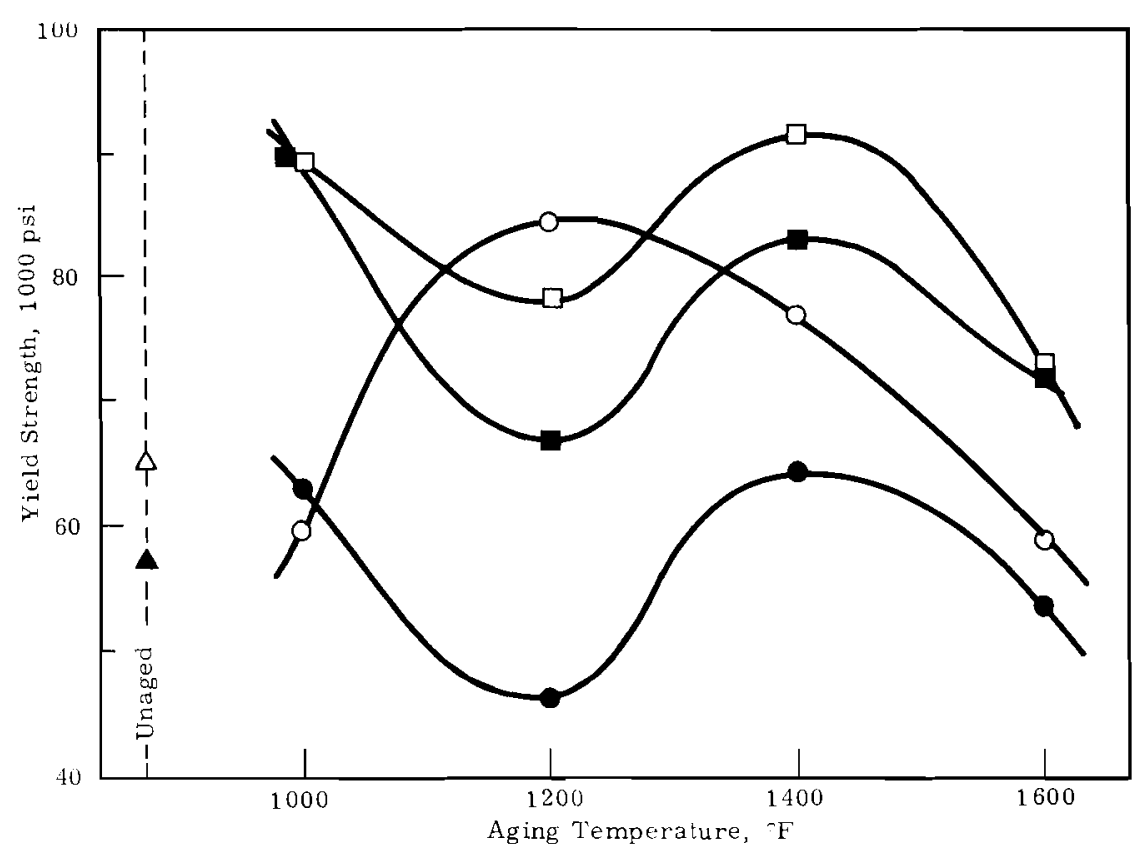

1000 hr Hastelloy X

$\triangle$ Unaged Hastelloy $W$

A Unaged Hastelloy $\mathrm{X}$

FIGURE 6. Room Temperature Tensile Test Properties of Unaged and Aged Hastelloy X and Hastelloy W Weld Metals 
The effect of aging in the temperature range of 1000 to $1600^{\circ} \mathrm{F}$ on the elevated temperature mechanical properties of the weld metals is shown in Figure 7 . The elevated temperature mechanical properties of the unaged weld metals appear to follow the trend (indicated by data in the literature) for wrought Hastelloy W and Hastelloy X. Unaged Hastelloy X weld metal maintains a much higher ductility over the temperature range in question than does unaged Hastelloy $W$ weld metal; the ductility of Hastelloy $W$ decreases to 16 to $17 \%$ when tested at 1400 and $1600{ }^{\circ} \mathrm{F}$. Unaged Hastelloy $\mathrm{X}$ tested between 1000 and $1600^{\circ} \mathrm{F}$ maintains a ductility of greater than $25 \%$. Over the same temperature range, the unaged weld metals maintain a relatively high level of yield strength, and there is very little difference between the yield strengths of either weld metal.

Aging of Hastellow W weld metal at $1000{ }^{\circ} \mathrm{F}$ decreases its ductility at $1000{ }^{\circ} \mathrm{F}$ to $18 \%$; there is very little difference in the ductility of the material aged 500 and $1000 \mathrm{hr}$ at $1000^{\circ} \mathrm{F}$. This aging of Hastelloy $\mathrm{W}$ at $1000{ }^{\circ} \mathrm{F}$ also results in an increase in its yield strength at this temperature. Again, there is very little difference between the yield strengths of the material aged 500 hr and the material aged $1000 \mathrm{hr}$. Aging Hastelloy $\mathrm{X}$ at $1000^{\circ} \mathrm{F}$ for 500 and $1000 \mathrm{hr}$ decreases its ductility to $16 \%$, but its yield strength is not significantly affected at that temperature.

Aging Hastelloy $W$ and Hastelloy $X$ at $1200^{\circ} \mathrm{F}$ significantly changes their $1200^{\circ} \mathrm{F}$ mechanical properties. Aging $500 \mathrm{hr}$ lowers the ductility of Hastelloy $W$ to $13 \%$ and the ductility of Hastelloy $X$ to $5 \%$. Continued aging for $1000 \mathrm{hr}$ results in overaging, with the ductilities of Hastelloy $\mathrm{W}$ and Hastelloy $X$ raised to 23 and $16 \%$, respectively. This aging of both weld metals at $1200{ }^{\circ} \mathrm{F}$ results in the yield strengths for the $500 \mathrm{hr}$ age being increased to values greater than $60,000 \mathrm{psi}$. The overaging caused by the $1000 \mathrm{hr}$ age lowers the yield strengths of both weld metals.

Aging of Hastelloy $W$ for $500 \mathrm{hr}$ at $1400{ }^{\circ} \mathrm{F}$ results in a decrease in the ductility at that temperature to $10 \%$ and an increase in yield strength at that temperature to $60,000 \mathrm{psi}$. Continued aging of Hastelloy $\mathrm{W}$ at $1400{ }^{\circ} \mathrm{F}$ for $1000 \mathrm{hr}$ does result in overaging and a decrease in yield strength to 28,000 psi but does not significantly change the $10 \%$ ductility at that temperature. 

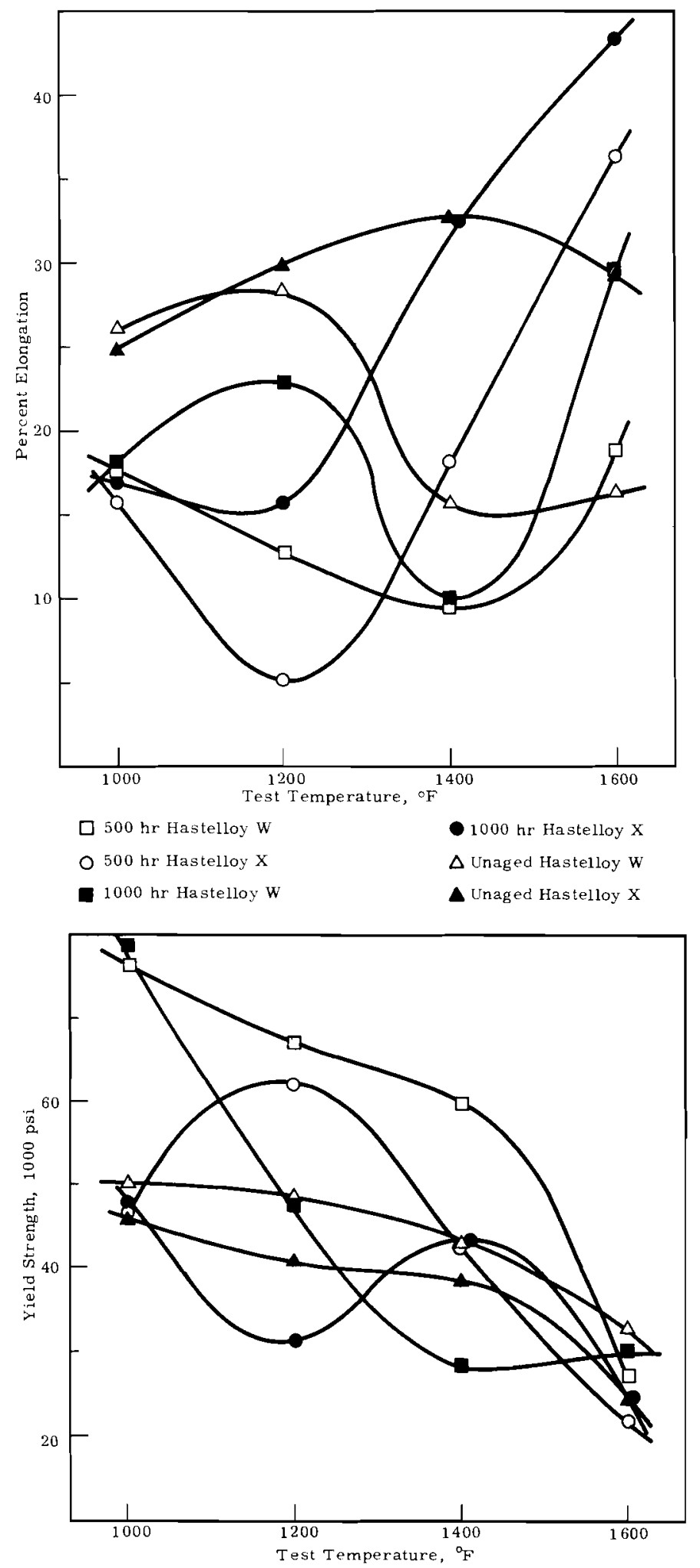

FIGURE 7. Elevated Temperature Tensile Test Properties of Unaged and Aged Hastelloy X and Hastelloy W Weld Metals 
Aging Hastelloy $\mathrm{X}$ for $500 \mathrm{hr}$ at $1400^{\circ} \mathrm{F}$ decreases the ductility at that temperature to $18 \%$, but does not significantly change the yield strength from the value of the unaged metal at that temperature. Continuted aging of Hastelloy $\mathrm{X}$ at $1400^{\circ} \mathrm{F}$ for $1000 \mathrm{hr}$ results in overaging, an increase in ductility at that temperature to $32 \%$, and does not significanily change its y:eld strength at that temperature.

Aging Hastelloy $\mathrm{W}$ for $500 \mathrm{hr}$ at $1600^{\circ} \mathrm{F}$ produces a slight recovery in ductility from the low value of $17 \%$ of the unaged weld metal at that temperature and a decrease in yieid strength to 22,000 psí. Continued aging of Hastelloy $W$ at $1600{ }^{\circ} \mathrm{F}$ for $1000 \mathrm{hr}$ results in overaging and an increase of ductility at that temperature to $30 \%$ and does not significantly change its yield strength at that temperature. Hastelloy $\mathrm{X}$ aged at $1600^{\circ} \mathrm{F}$ for $500 \mathrm{hr}$ results in an increase in ductility at that temperature to $36 \%$ and a decrease in yield strength at that temperature to 22,000 psi. Continued aging of Hasteiloy $X$ for 1000 hr at $i 600^{\circ} \mathrm{F}$ results in still further increase in its ductijity ar $1600^{\circ} \mathrm{F}$ to $44 \%$ and a slight recovery in yield strength at $1600^{\circ} \mathrm{F}$ to 24,000 psi.

The room temperature mechanical properties of Hastelloy X-280 base metal and Haynes 25 base metal aged for 500 and $1000 \mathrm{hr}$ at the temperatures of $1000,1200,1400$, and $1600^{\circ} \mathrm{F}$ are shown in Figure 8. As shown in the figure, there is very little difference in the ductility or yield strength of Hastelloy X-280 aged at 500 and $1000 \mathrm{hr}$ at any of the se aging temperatures. There is also very little difference in the room temperature ducility on yield strength of Haynes 25 aged at 1400 and $1600^{\circ} \mathrm{F}$ for 500 or $1000 \mathrm{hr}$. Although the figures do indisate that both of these base metals suffex from some age embrittlement in this temperature range the minimum duct:lities are approximately $10 \%$.

The elevated temperature mechanical properties of Hastelicy X-280 base metal and Haynes 25 base metaì are shown in Figure 9 . As indicated in the figure aging 500 and $2000 \mathrm{hr}$ at the indicated aging temperatures does not significantly change the mechanical properties of Hastelloy X-280 at these test temperatures. There is some effect of age embrittlement on the elevated temperature mechanicai properties of Haynes 25 aged and tested 

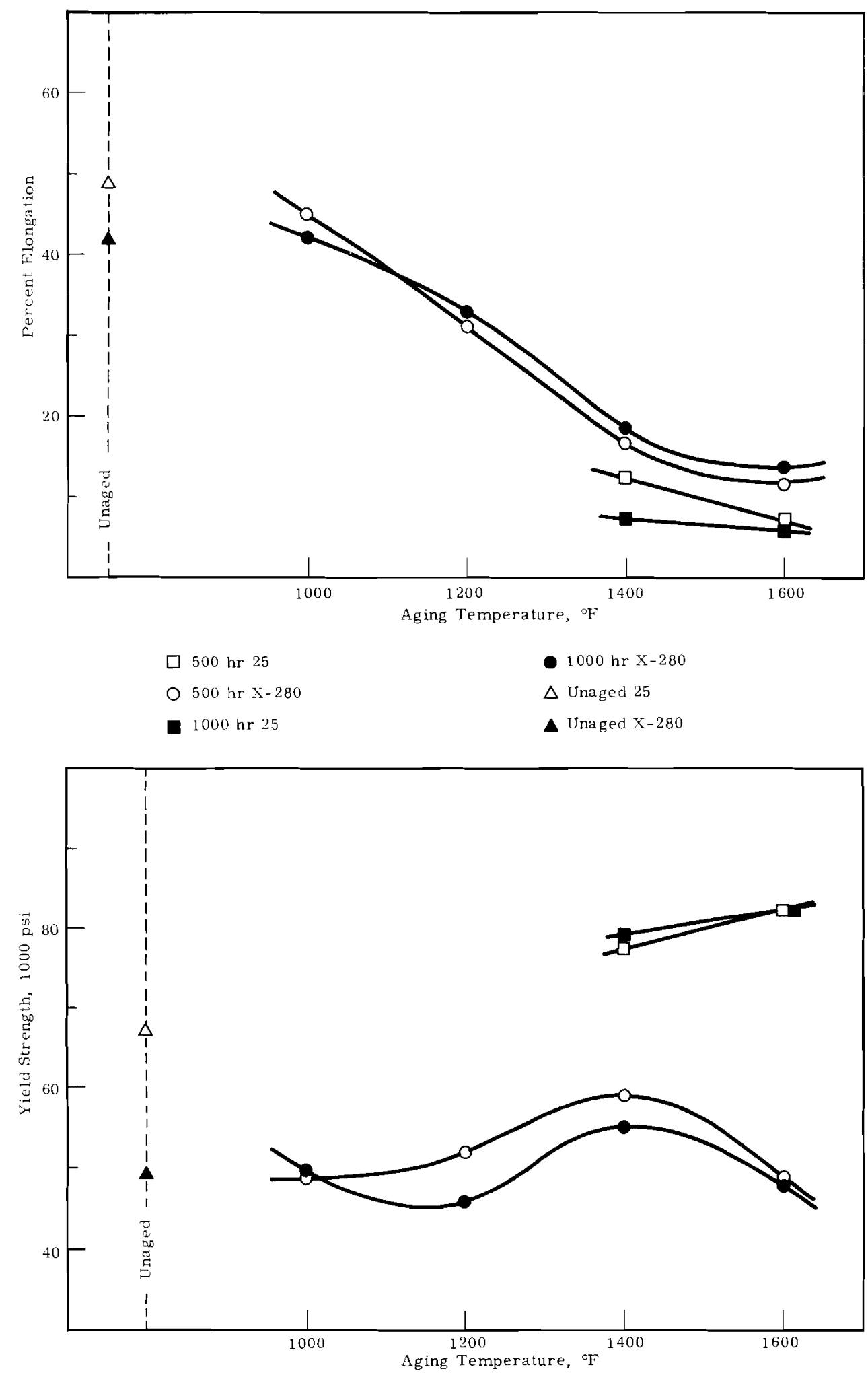

FIGURE 8. Room Temperature Tensile Test Properties of Unaged and Aged Hastelloy X-280 and Haynes 25 Base Metals 

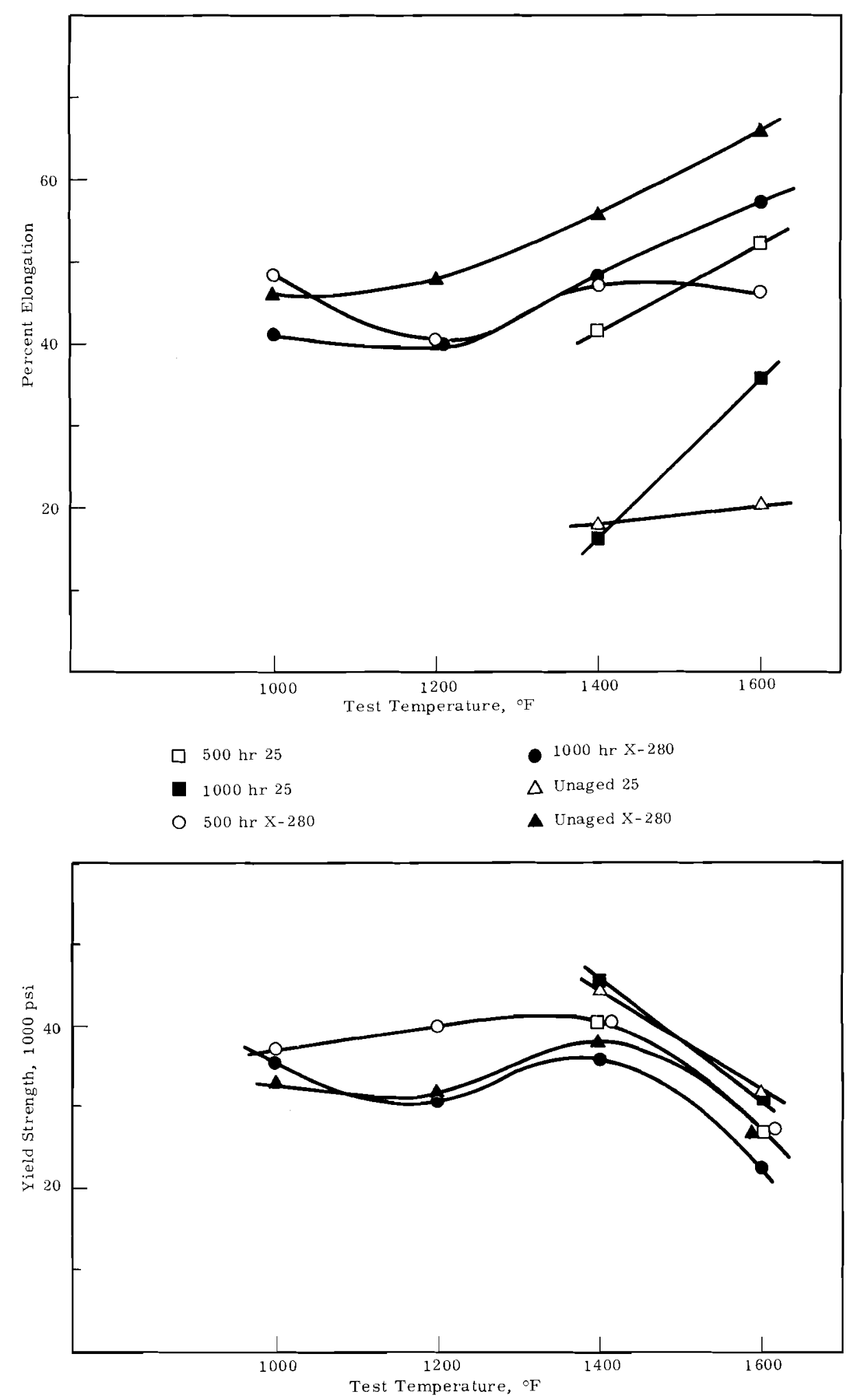

FIGURE 9. Elevated Temperature Tensile Test Properties of Unaged and Aged Hastelloy X-280 and Haynes 25 Base Metals 
at 1400 and $1600^{\circ} \mathrm{F}$. Aging Haynes 25 for $500 \mathrm{hr}$ at 1400 and $1600^{\circ} \mathrm{F}$ results in an increase in ductility at the se temperatures to over $40 \%$. Continued aging for a period of $1000 \mathrm{hr}$ at 1400 and $1600{ }^{\circ} \mathrm{F}$ results in embrittlement of Haynes 25 and a decrease in the ductility af $1400^{\circ} \mathrm{F}$ to a value close to the unaged materials ductility. It also results in a decrease in the ductility at $1600^{\circ} \mathrm{F}$ to a value that is still $80 \%$ higher than the unaged materials ductility at that temperature.

\section{HARDNESS STUDIES}

The effects of aging for 500 and $1000 \mathrm{hr}$ at 1000 and $1200{ }^{\circ} \mathrm{F}$ on the room temperature hardness of welded joints of Hastelloy X-280 to 316 SS with Hastelloy $\mathrm{X}$ weld metal are shown in Figure 10 . The hardness

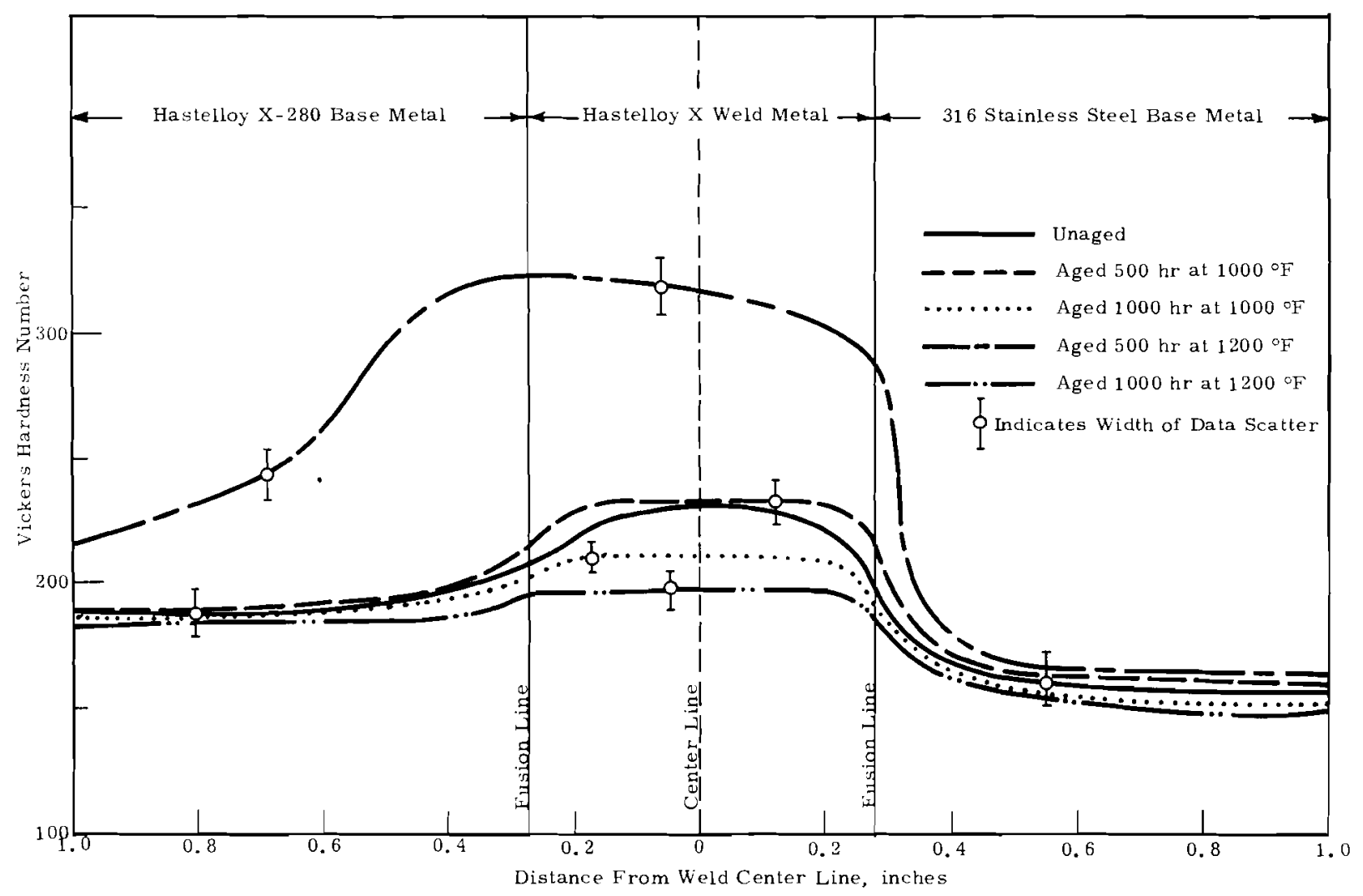

FIGURE 10. Room Temperature Hardness Profiles of Unaged and Aged Weld Specimens of Hastelloy X-280 to AISI 316 Stainless Steel with Hastelloy X Weld Metal 
traverses indicate the most significant hardening of this welded joint occurs with the $500 \mathrm{hr}$ age at $1200^{\circ} \mathrm{F}$. This aging for $500 \mathrm{hr}$ at $1200^{\circ} \mathrm{F}$ causes significant hardening of both Hastelloy X-280 base metal and Hastelloy X weld metal. Aging for $500 \mathrm{hr}$ at $1000^{\circ} \mathrm{F}$ does not significantly change the hardness of the base metals or the weld metal. Aging for $1000 \mathrm{hr}$ at 1000 and $1200^{\circ} \mathrm{F}$ causes overaging and the hardness of this joint is lowered to a value less than the hardness of the unaged joint.

The effects of aging for 500 and $1000 \mathrm{hr}$ at 1000 and $1200{ }^{\circ} \mathrm{F}$ on the room temperature hardness of welded joints of Hastelloy X-280 to 316 SS with Hastelloy W weld metal are shown in Figure 11. These hardness

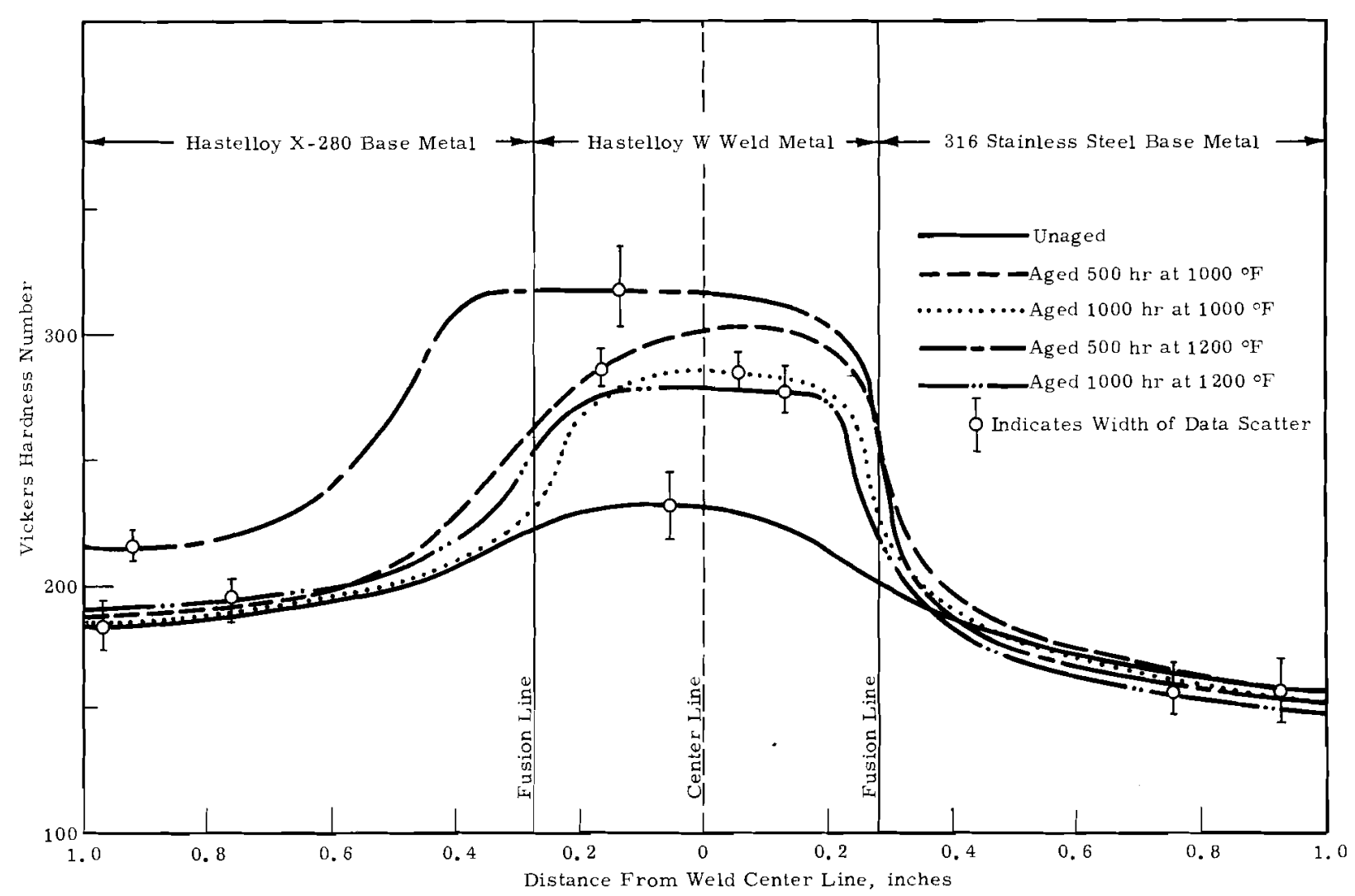

FIGURE 11. Room Temperature Hardness Profiles of Unaged and Aged Weld Specimens of Hastelloy X-280 to AISI 316 Stainless Steel with Hastelloy W Weld Metal

traverses indicate that there is significant age hardening of the weld metal when aged at all four of the aging conditions. In addition there is considerable 
age hardening of the Hastelloy X-280 base metal aged $500 \mathrm{hr}$ at $1200^{\circ} \mathrm{F}$. The hardening of this Hastelloy $\mathrm{W}$ welded joint aged $500 \mathrm{hr}$ at $1200{ }^{\circ} \mathrm{F}$ is very similar to the hardening of the Hastelloy $\mathrm{X}$ welded joint aged $500 \mathrm{hr}$ at $1200{ }^{\circ} \mathrm{F}$. Aging for $1000 \mathrm{hr}$ at $1200{ }^{\circ} \mathrm{F}$ causes overaging of this joint, with the Hastelloy X-280 base metal returning to the hardness level of the unaged base metal but the Hastelloy $W$ weld metal only recovers to a point that is still significantly above the hardness of the unaged weld metal。 Aging for $500 \mathrm{hr}$ at $1000^{\circ} \mathrm{F}$ does not significantly change the hardness of the Hastelloy X-280 base metal but significantly changes the hardness of the Hastelloy $\mathrm{W}$ weld metal. Aging for $1000 \mathrm{hr}$ at $1000^{\circ} \mathrm{F}$ does not appreciably change the hardness of this joint from the hardness of the same joint aged $500 \mathrm{hr}$ at $1000^{\circ} \mathrm{F}$. Each of these four aging treatments on this welded joint result in a hardness profile that has a sharp transition in hardness going from Hastelloy $\mathrm{X}-280$ base metal to Hastelloy W weld metal and back down to 316 SS base metal. As expected the hardness of the 316 SS base metal does not significantly change with these aging treatments.

The effects of aging 500 and $1000 \mathrm{hr}$ at 1400 and $1600{ }^{\circ} \mathrm{F}$ on the room temperature hardness of welded joints of Hastelloy X-280 to Haynes 25 with Hastelloy $\mathrm{X}$ weld metal are shown in Figure 12. These hardness traverses indicate that there is significant age hardening in both base metals and Hastelloy $X$ weld metal. It is interesting to note that aging causes more hardening in the Haynes 25 base metal than in either Hastelloy $X$ weld metal or Hastelloy X-280 base metal. In the joints that have been aged $500 \mathrm{hr}$ at $1600^{\circ} \mathrm{F}, 1000 \mathrm{hr}$ at $1600^{\circ} \mathrm{F}$, and $1000 \mathrm{hr}$ at $1400^{\circ} \mathrm{F}$, there is a sharp transition of hardness in going from Hastelloy X-280 base metal to Haynes 25 base metal. Aging $500 \mathrm{hr}$ at $1400^{\circ} \mathrm{F}$ results in significant age hardening in both base metals and weld metal but there is not much difference in hardness across the welded joint. Age hardening is indicated to be slower in the Haynes 25 base metal than the Hastelloy $\mathrm{X}$ weld metal but the ultimate hardness of the aged Haynes 25 base metal is considerably higher than the hardness of the aged Hastelloy $\mathrm{X}$ weld metal. The unaged joint has a sharp transition in hardness between Hastelloy X weld metal and Haynes 25 base metal. 


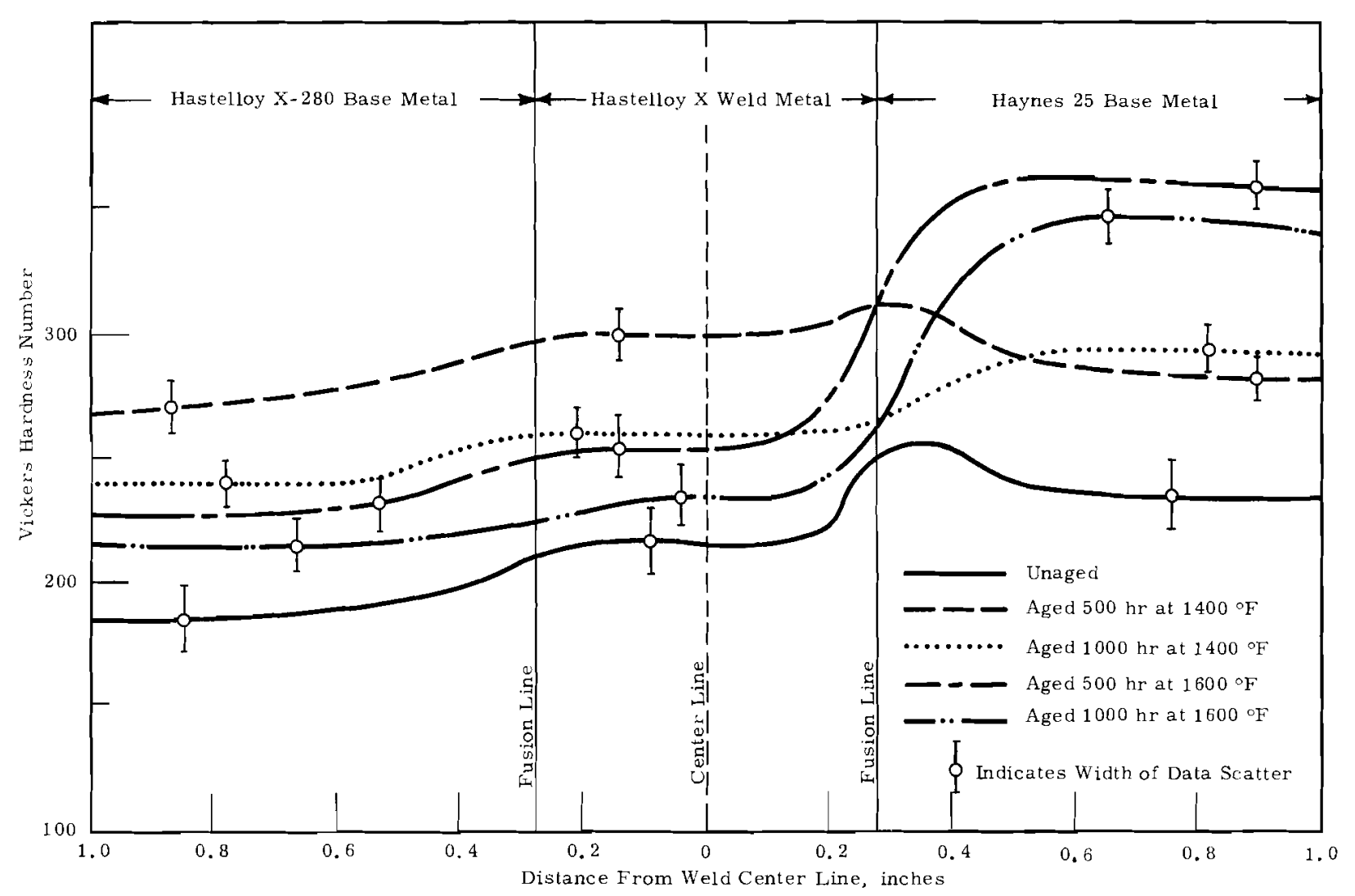

FIGURE 12. Room Temperature Hardness Profiles of Unaged and Aged Weld Specimens of Hastelloy X-280 to Haynes 25 with Hastelloy X weld Metal

The effects of aging for 500 and $1000 \mathrm{hr}$ at 1400 and $1600^{\circ} \mathrm{F}$ on the room temperature hardness of welded joints of Hastelloy X-280 to Haynes 25 with Hastelloy W weld metal are shown in Figure 13. These hardness traverses indicate there is more hardening in the weld metal of this joint than there is in the Hastelloy $X$ weld metal of the similar joint. This hardening of the weld metal results in abrupt hardness transitions across the fusion zones of Hastelloy W weld metal to Haynes 25 and Hastelloy $\mathrm{X}-280$ base metals. Aging $500 \mathrm{hr}$ at $1400{ }^{\circ} \mathrm{F}$ results in the most severe hardening of Hastelloy X-280 base metal and Hastelloy W weld metal. Aging for $1000 \mathrm{hr}$ at $1400{ }^{\circ} \mathrm{F}$ causes overaging of Hastelloy X-280 and Hastelloy $\mathrm{W}$ but there still is a sharp transition in hardness across the fusion zones between the weld metal and the two base metals. Aging $500 \mathrm{hr}$ 
at $1600^{\circ} \mathrm{F}$ produces the most significant hardening of Haynes 25. Aging for $1000 \mathrm{hr}$ at $1600^{\circ} \mathrm{F}$ does not significantly change the hardness profile of this welded joint from the hardness of the same welded joint aged $500 \mathrm{hr}$ at $1600^{\circ} \mathrm{F}$. All of these hardness traverses indicate that the aging results in abrupt transitions in hardness at both weld fusion zones. In addition, the unaged joint has a high hardness at the fusion zone between Hastelloy W and Haynes 25.

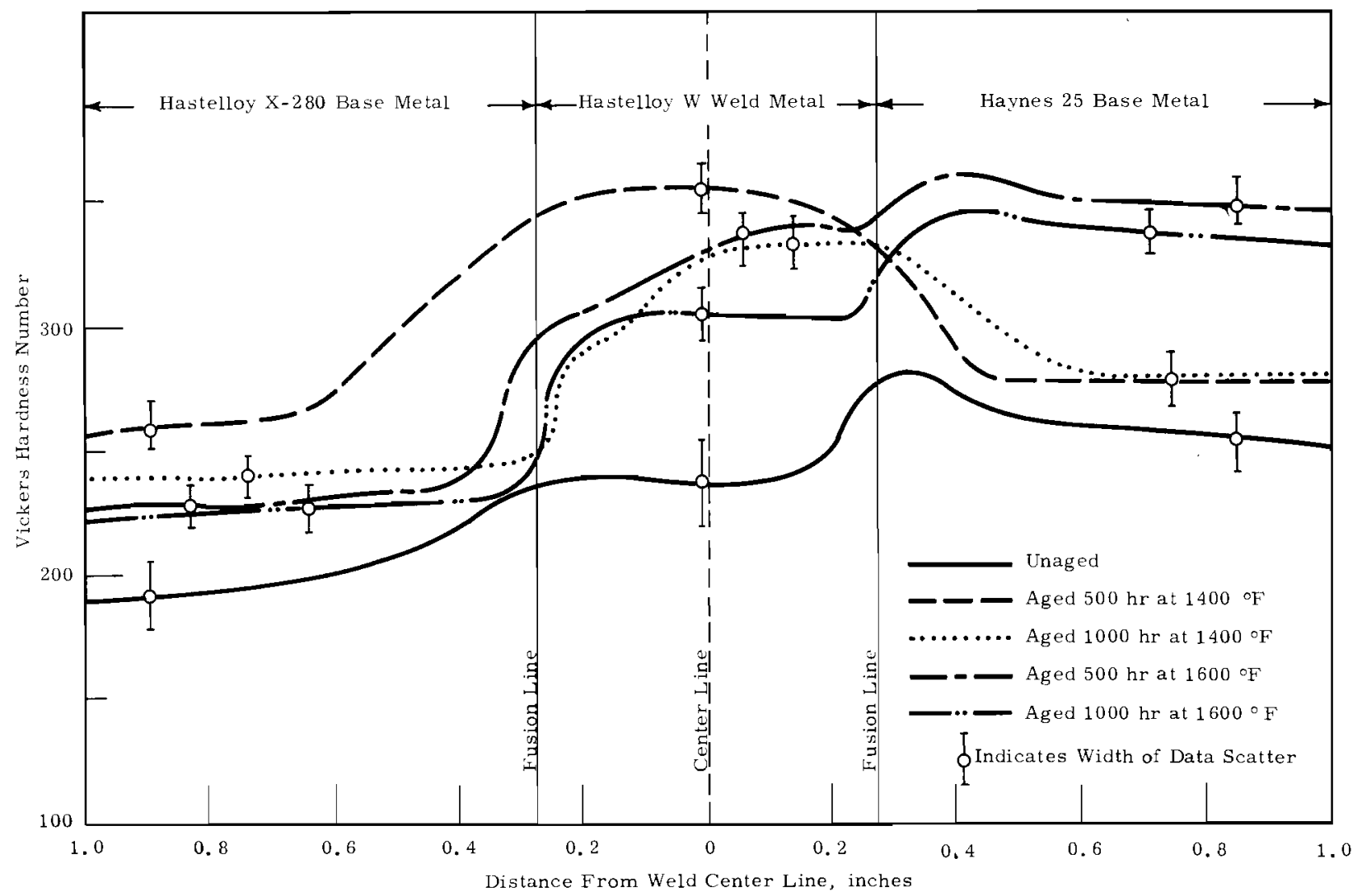

FIGURE 13. Room Temperature Hardness Profiles of Unaged and Aged Weld Specimens of Hastelloy X-280 to Haynes 25 with Hastelloy W Weld Metal

\section{MET ALLOGR APHIC EXAMINATIONS}

The microstructure of Hastelloy $\mathrm{W}$ weld metal in the unaged condition is shown in Figure 14. The unaged microstructure has a significant amount of inclusions and carbides probably $\mathrm{M}_{6} \mathrm{C}$, randomly distributed within the grains. The effects of aging 500 and $1000 \mathrm{hr}$ at 1000,1200 , 

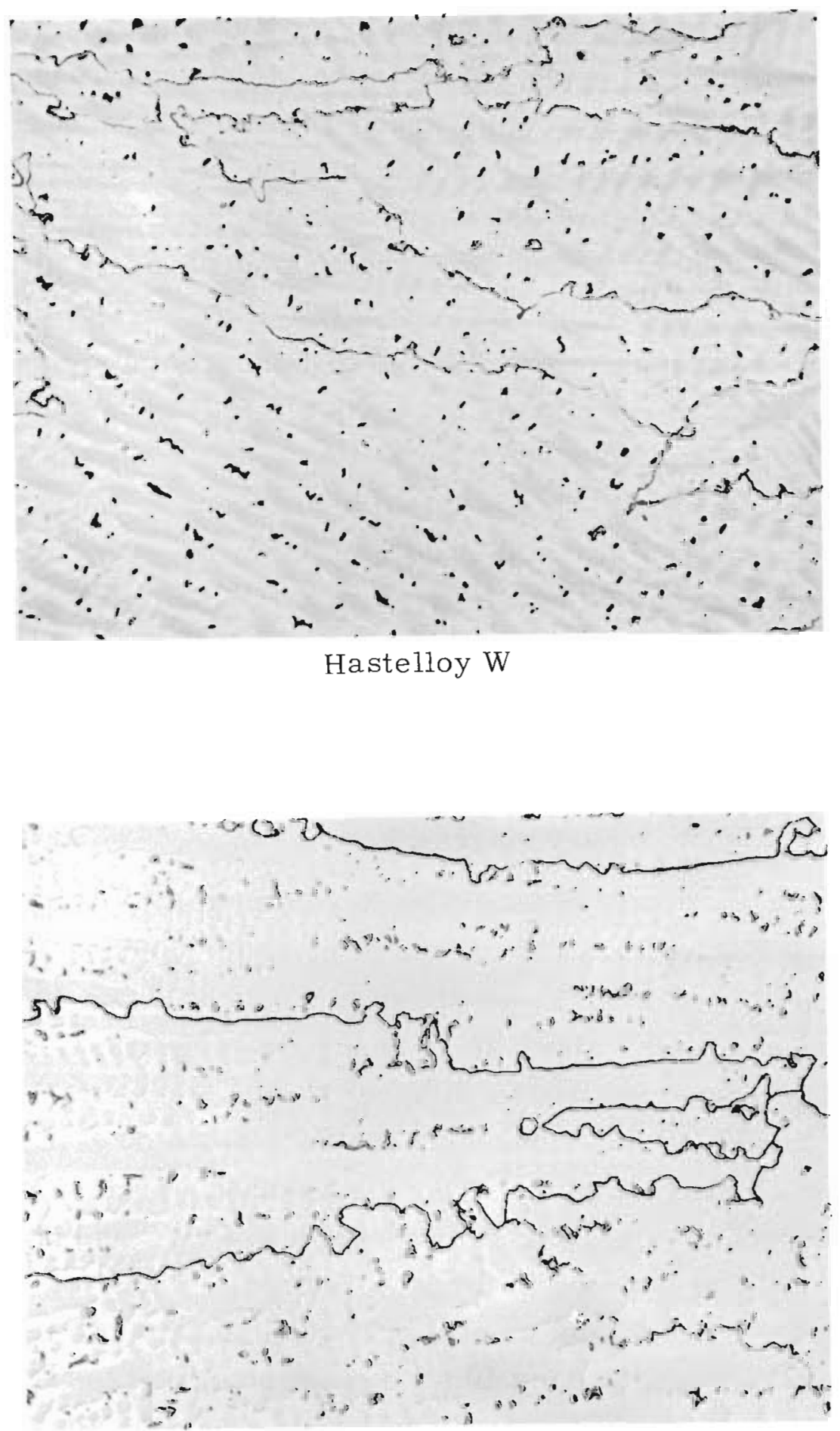

Hastelloy X

FIGURE 14. Unaged Hastelloy X and Hastelloy W Weld Metal, $500 \mathrm{X}$ 
1400, and $1600^{\circ} \mathrm{F}$ are shown in Figures 15 and 16 . Aging at $1000^{\circ} \mathrm{F}$ causes significant second phase precipitation at the grain boundaries and between the dendrites. There is not much difference between the microstructures of this weld metal aged $500 \mathrm{hr}$ at $1000^{\circ} \mathrm{F}$ and aged $500 \mathrm{hr}$ at $1200^{\circ} \mathrm{F}$, and between the microstructures of this metal aged $1000 \mathrm{hr}$ at $1000^{\circ} \mathrm{F}$ and aged $1000 \mathrm{hr}$ at $1200^{\circ} \mathrm{F}$. The $1000 \mathrm{hr}$ exposure at $1200{ }^{\circ} \mathrm{F}$ results in a very complicated carbide network within the grains. Aging for $500 \mathrm{hr}$ at $1400^{\circ} \mathrm{F}$ produces a Widmanstatten-type precipitate concentrated near the grain boundaries. Continued aging for $1000 \mathrm{hr}$ at $1400^{\circ} \mathrm{F}$ causes some of the Widmanstatten precipitate to agglomerate but the Widmanstatten structure is still present. This precipitate produced at $1400^{\circ} \mathrm{F}$ corresponds to the beta phase of the nickel-molybdenum binary diagram. Aging at $1600^{\circ} \mathrm{F}$ also produces a Widmanstatten precipitate but the precipitate network for $500 \mathrm{hr}$ at $1600^{\circ} \mathrm{F}$ is much coarser than the network for $500 \mathrm{hr}$ at $1400^{\circ} \mathrm{F}$. Aging $1000 \mathrm{hr}$ at $1600^{\circ} \mathrm{F}$ causes the precipitate to agglomerate to a point where the Widmanstatten precipitate network is no longer present. This precipitate produced at $1600^{\circ} \mathrm{F}$ corresponds to the gamma phase of the nickel-molybdenum binary diagram.

The microstructure of Hastelloy $X$ weld metal in the unaged condition is shown in Figure 14. The effects of aging for 500 and $1000 \mathrm{hr}$ at $1000,1200,1400$, and $1600^{\circ} \mathrm{F}$ are shown in Figures 17 and 18. Aging for $500 \mathrm{hr}$ at $1000^{\circ} \mathrm{F}$ does not appreciably change the appearance of the microstructure. The unaged and $500 \mathrm{hr}$ at $1000^{\circ} \mathrm{F}$ aged microstructures indicate a significant amount of inclusions and carbides, probably $\mathrm{M}_{6} \mathrm{C}$, randomly distributed within the grains. (11) The second phases precipitated at all four aging temperatures are probably a mixture of $\mathrm{M}_{6} \mathrm{C}$ and $\mathrm{M}_{23} \mathrm{C}_{6}$, with the majority of the precipitate in the $\mathrm{M}_{6} \mathrm{C}$ form. ${ }^{(8)}$ Aging for $1000 \mathrm{hr}$ at $1000{ }^{\circ} \mathrm{F}$ produces a significant amount of carbide precipitate in the grain boundaries and between the dendrites. Aging $500 \mathrm{hr}$ at $1200 \mathrm{~F}$ produces a large amount of a very fine carbide precipitate between the dendrites. Continued aging for $1000 \mathrm{hr}$ at $1200^{\circ} \mathrm{F}$ overages the structure and produces carbide precipitate clusters around large carbides within the grains and relatively massive carbides in the grain boundaries. Aging at $1400^{\circ} \mathrm{F}$ produces a very fine precipitate randomly distributed within the grains. 
Q.

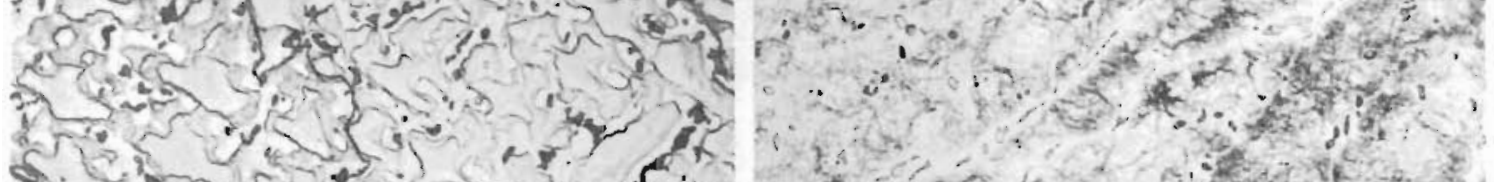
Lent on

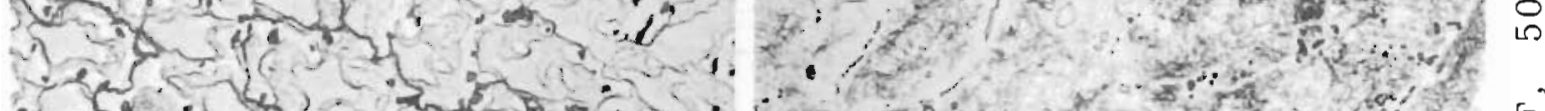

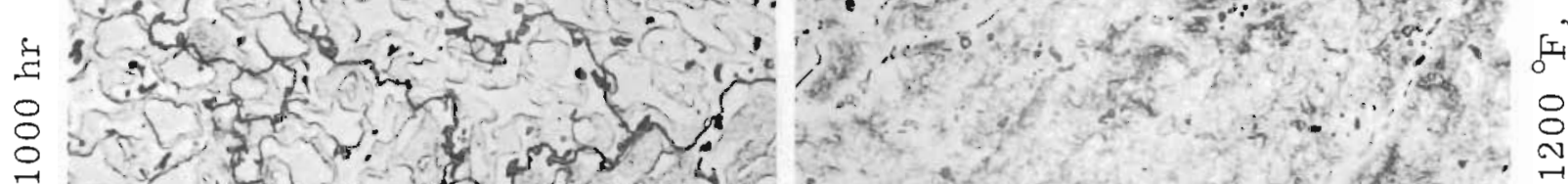
Q

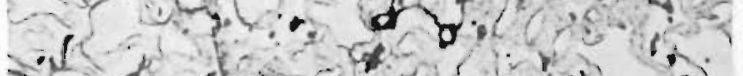

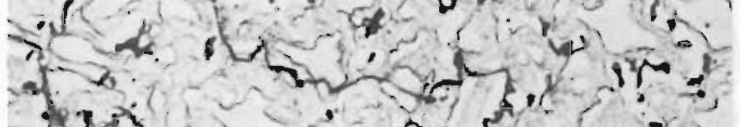

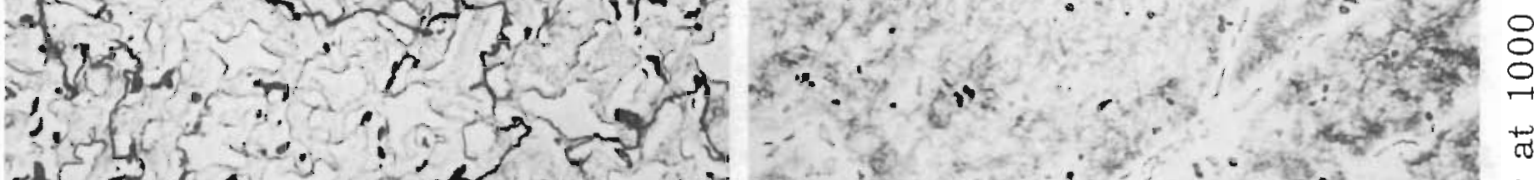

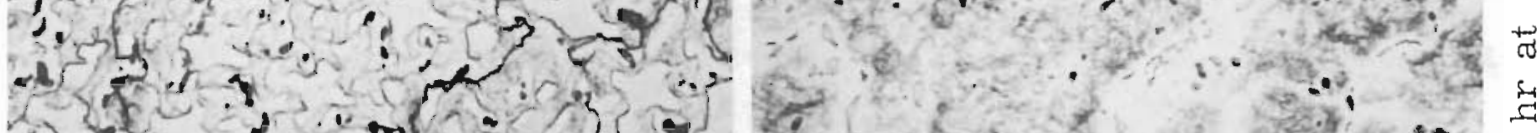

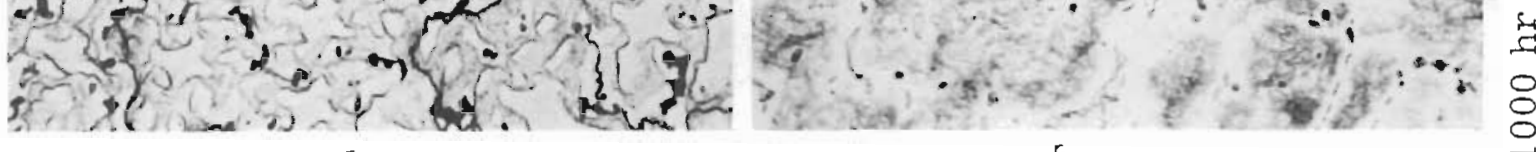

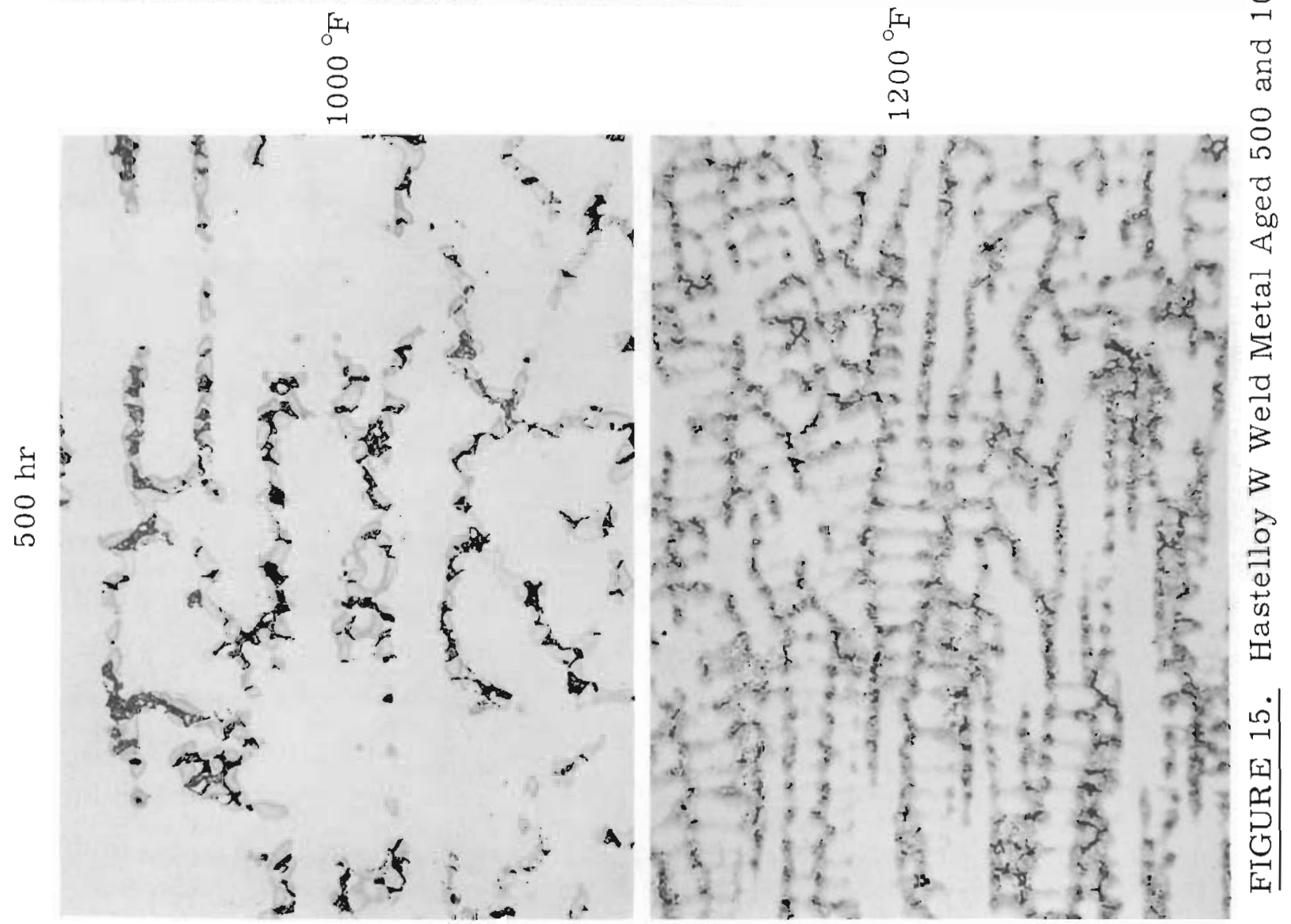



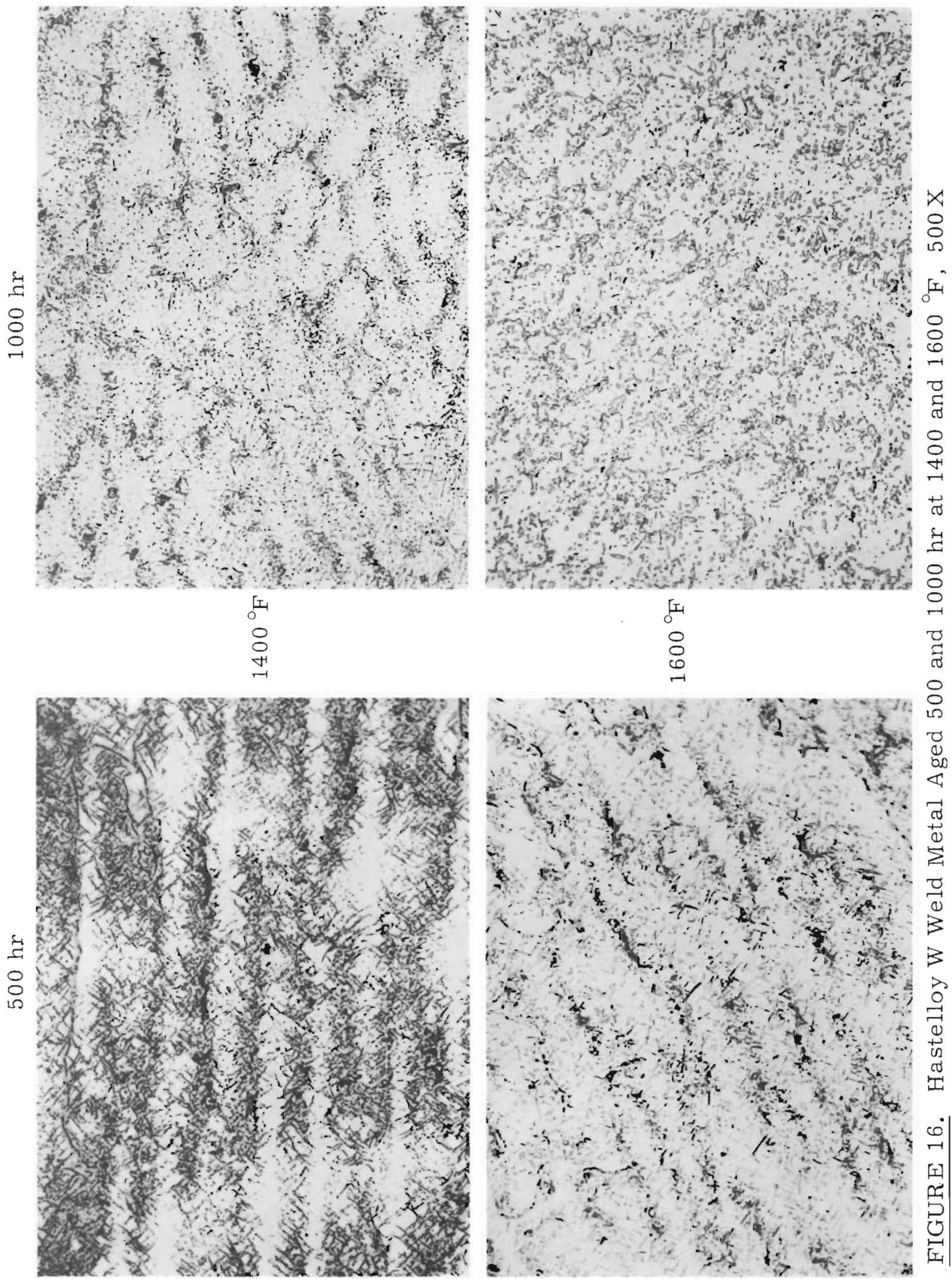


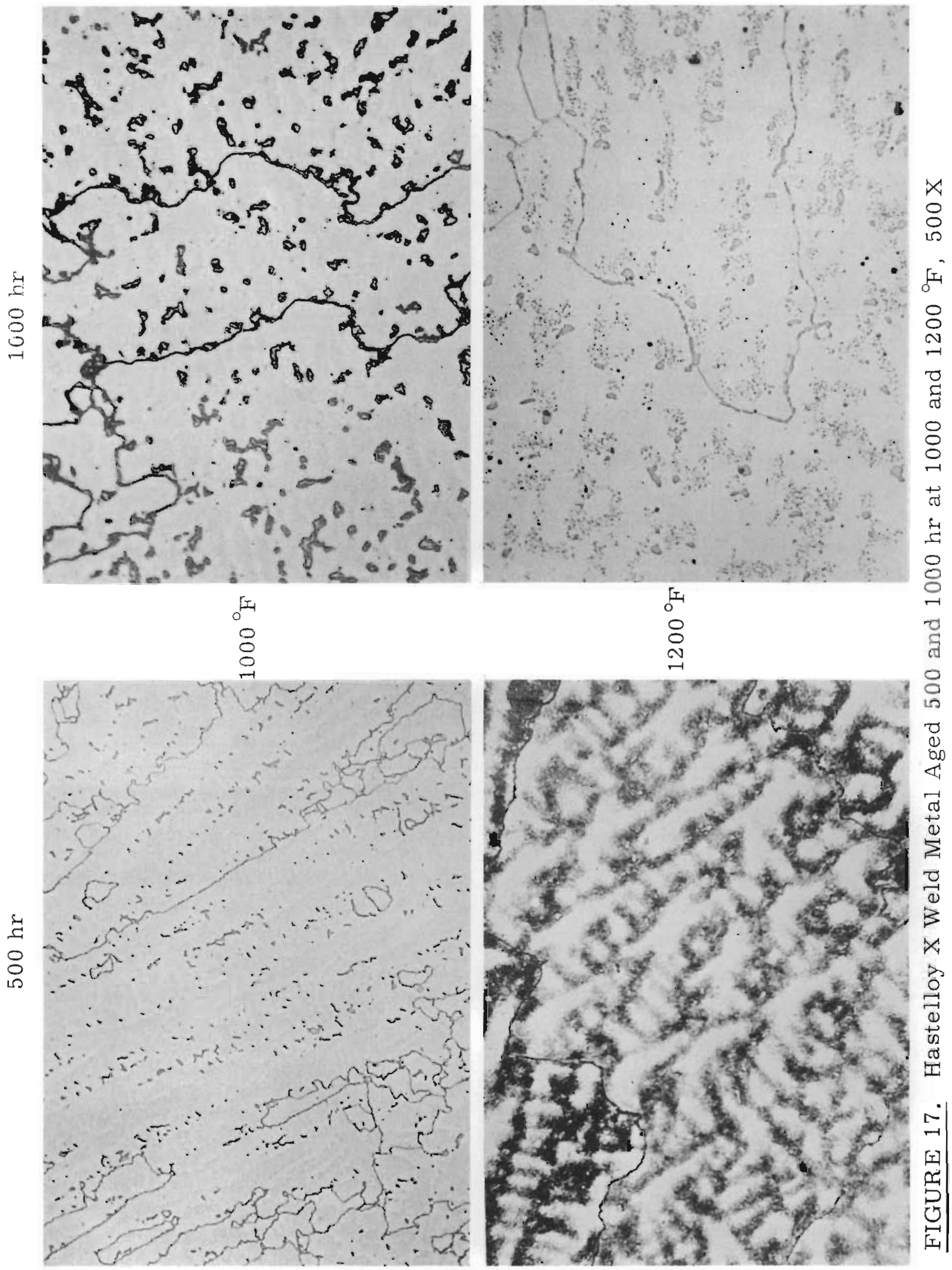



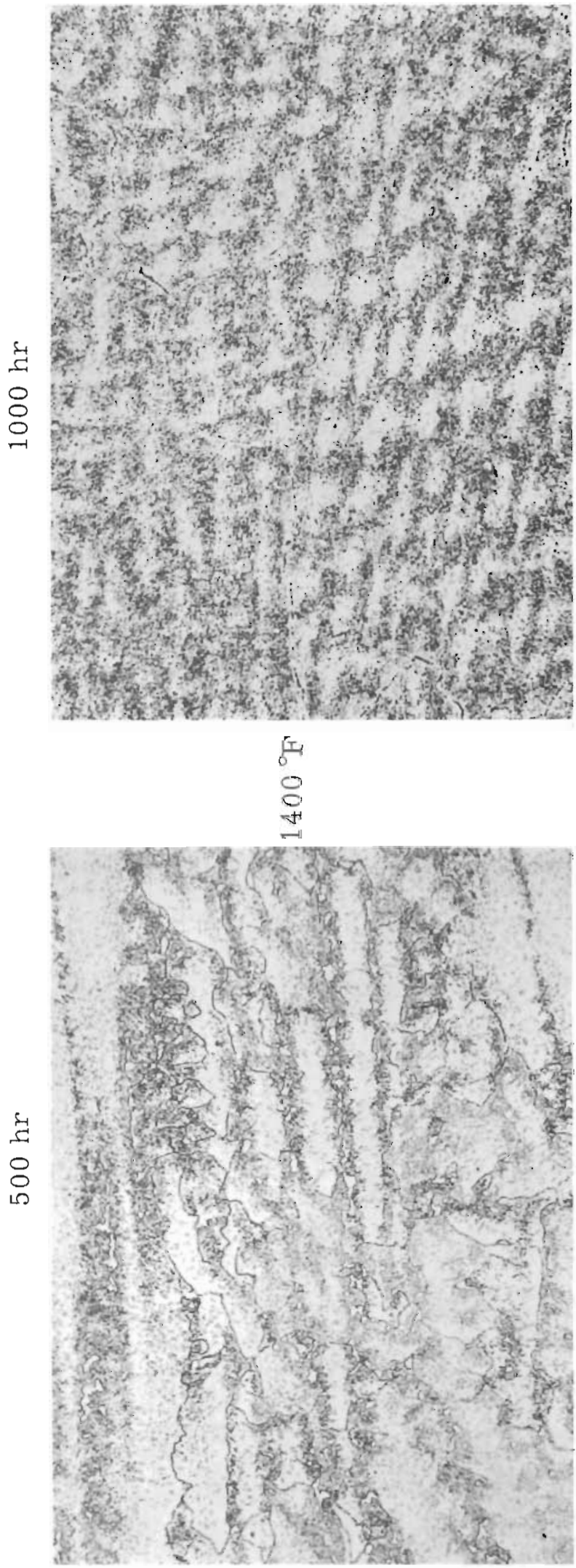

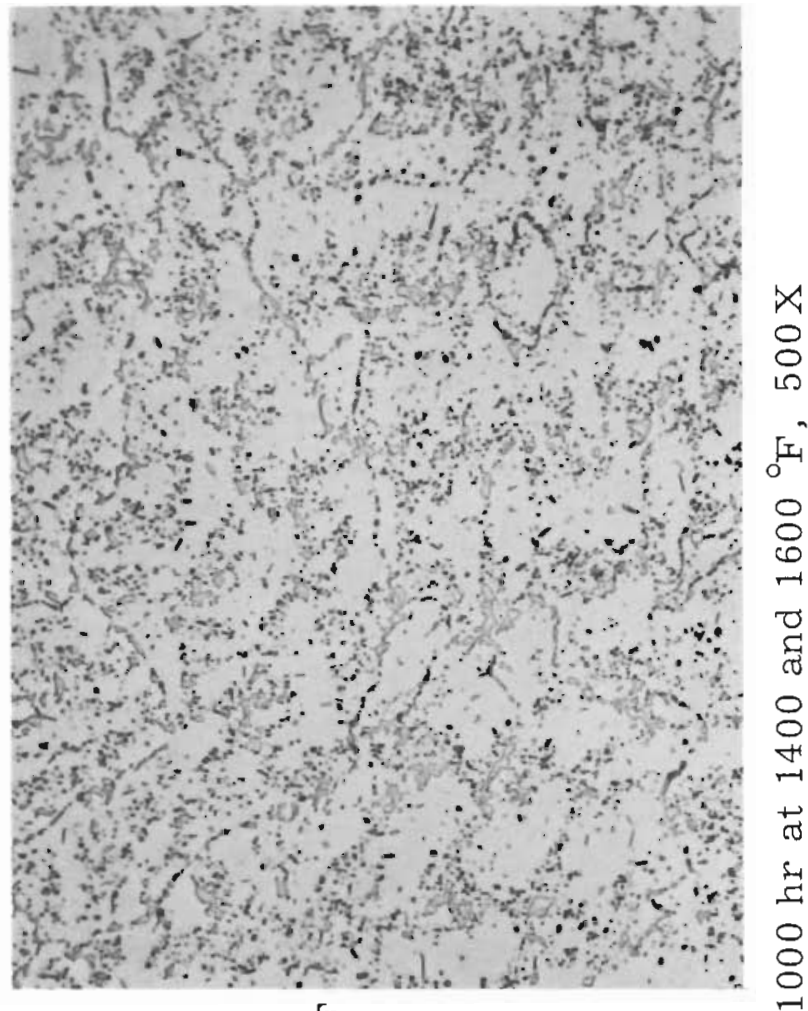

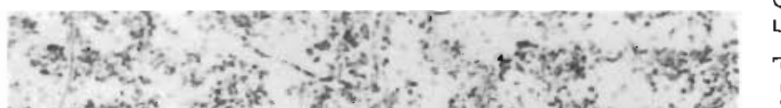

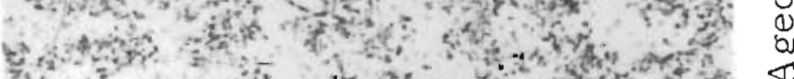

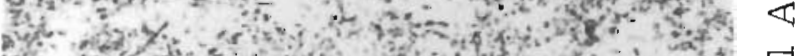

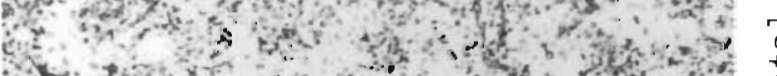

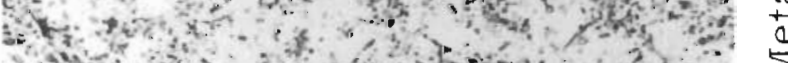

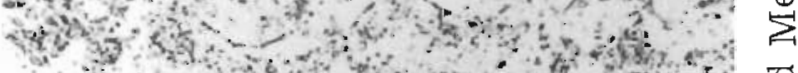

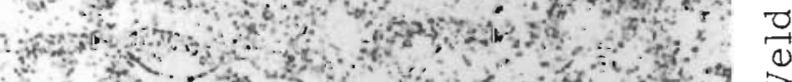
3. 3wn

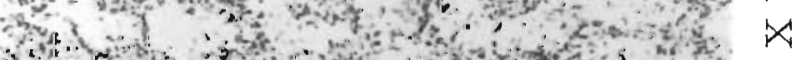
6.

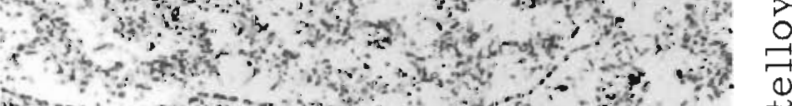

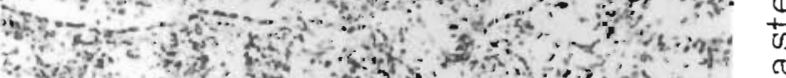
a

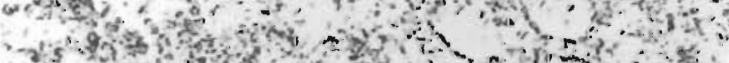

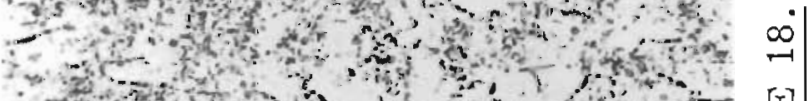

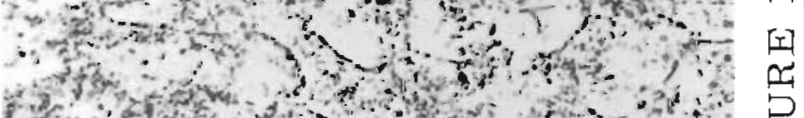

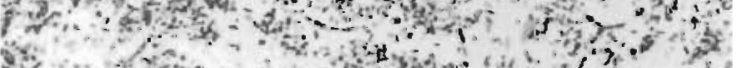

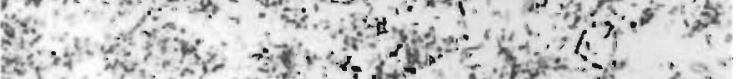

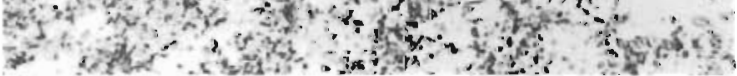


There appears to be more precipitate produced, at $1400^{\circ} \mathrm{F}$, by the $1000 \mathrm{hr}$ age than the 500 hr age but the particles are still hard to rescive at $500 \mathrm{X}$. Aging at $1600^{\circ} \mathrm{F}$ produces relatively large precipitate particies randomly distributed within the grains as well as in the grain boundaries. The $1000 \mathrm{hr}$ age at $\$ 600^{\circ} \mathrm{F}$ results in agglomeration of the particles produced by the $500 \mathrm{hr}$ age at $1600 \mathrm{\circ}$.

The microstructure of Haste110Y X-280 plate in the solution treated condition is shown in Figure 19. The effects of aging for 500 and $1000 \mathrm{hr}$ at $1000,1200,1400$, and $1600^{\circ} \mathrm{E}$ on the microstructure of Haste1loy X -280 plate are showin in Figures 20 and 21 . The second phases precipitated at all four aging temperatures are probably a mixture of $\mathrm{M}_{6} \mathrm{C}$ and $\mathrm{M}_{23} \mathrm{C}_{6}$, with the majority of the precipitate in the $\mathrm{M}_{6} \mathrm{C}$ form. (8) Aging at $1000 \mathrm{~F}$ produces a continuous carbide network in the grain boundaries and heterogereously scattered within the grains. Aging 500 hr at $1200^{\circ} \mathrm{F}$ produces a thick continucus carbide netxork in the grain boundaries and a fine carbide precipitate on the tw in planes. Continued aging of $1000 \mathrm{nr}$ at $1200{ }^{\circ} \mathrm{F}$ causes considerable agglomeration of the grain boundary carbides and the development of a random distribution of carbides within the grains. Aging a: $1400^{\circ} \mathrm{F}$ produces a large amount of carbide precipitate in the grain boundartes and randomly distributed within the grains. Aging at $1600^{\circ} \mathrm{F}$ also produces a large amount of carbide precipitate in the grain boundaries and within the grains, but there is less precipitate developed at 1600 "F than there was at 1400 F. At 1400 ard $1600^{\circ} \mathrm{F}$ there is not an appreciable difference. between the microstructures produced by aging $500 \mathrm{hr}$ and by aging $1000 \mathrm{hr}$.

The microstructure of Haynes 25 plate in the solution treated condition is shown in Figure 19. The effects of aging 500 and ic00 hr at 1400 and $1600^{\circ} \mathrm{F}$ are shown in Figure 22. Aging $500 \mathrm{hr}$ at $1400^{\circ} \mathrm{F}$ produces a precipitate, probabiy the Laves phase, network in the grain boundaries. Continued aging of $1000 \mathrm{hr}$ at $1400^{\circ} \mathrm{F}$ produces an extensive precipitate network on the twin planes. Aging $500 \mathrm{hr}$ at $1600 \mathrm{~F}$ produces a microstructure similar to the $1000 \mathrm{hr}$ at $1400^{\circ} \mathrm{F}$ aged microstructure except the precipitate particles are larger in the $1600^{\circ} \mathrm{F}$ microstructure than the $1400^{\circ} \mathrm{F}$ micro" structure. There is no significant difference between the $1600^{\circ} \mathrm{F}$ microstructures aged 500 and $1000 \mathrm{hr}$. 


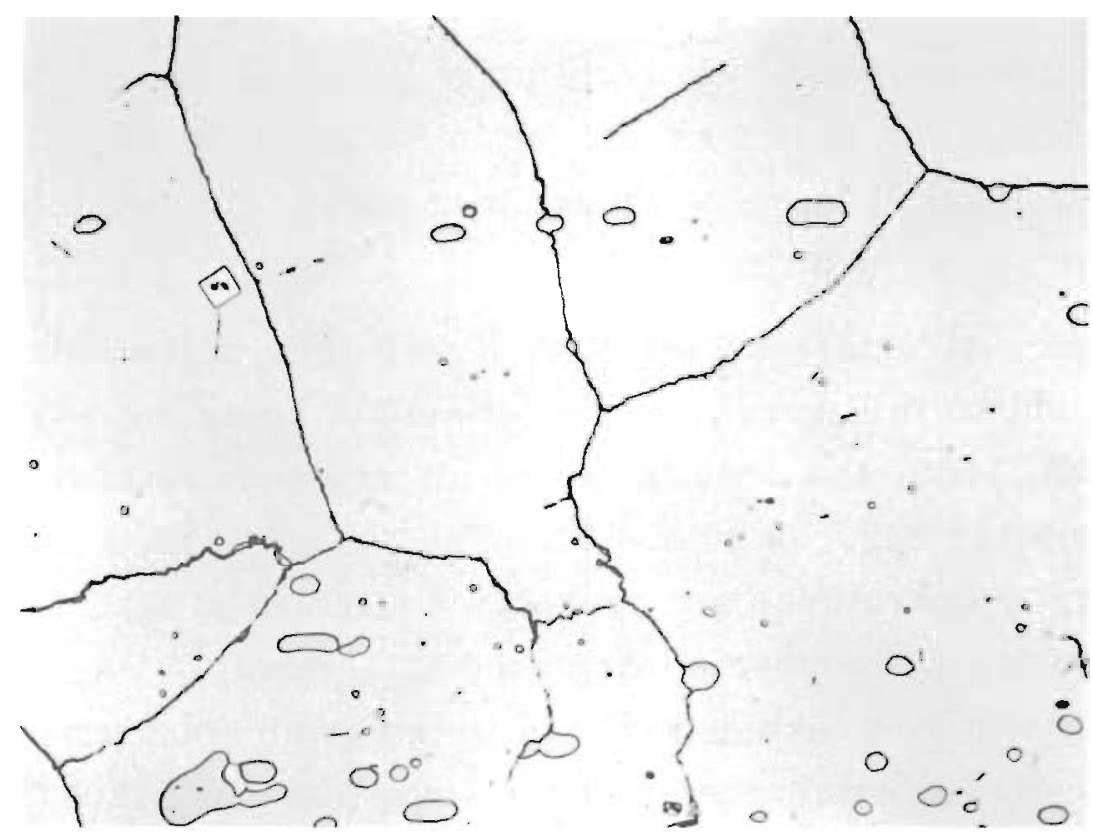

Hastelloy $X-280$

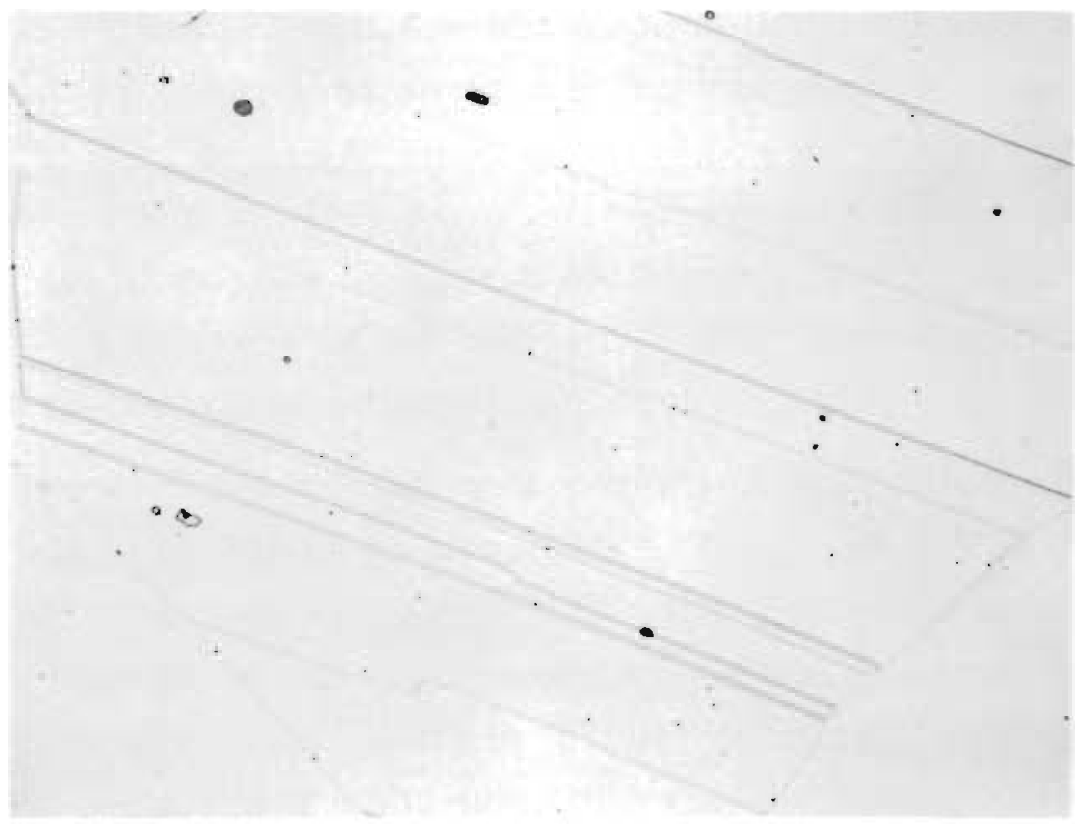

Haynes 25

FIGURE 19. Unaged Hastelloy X-280 and Haynes 25 Base Metals, $500 \mathrm{X}$ 


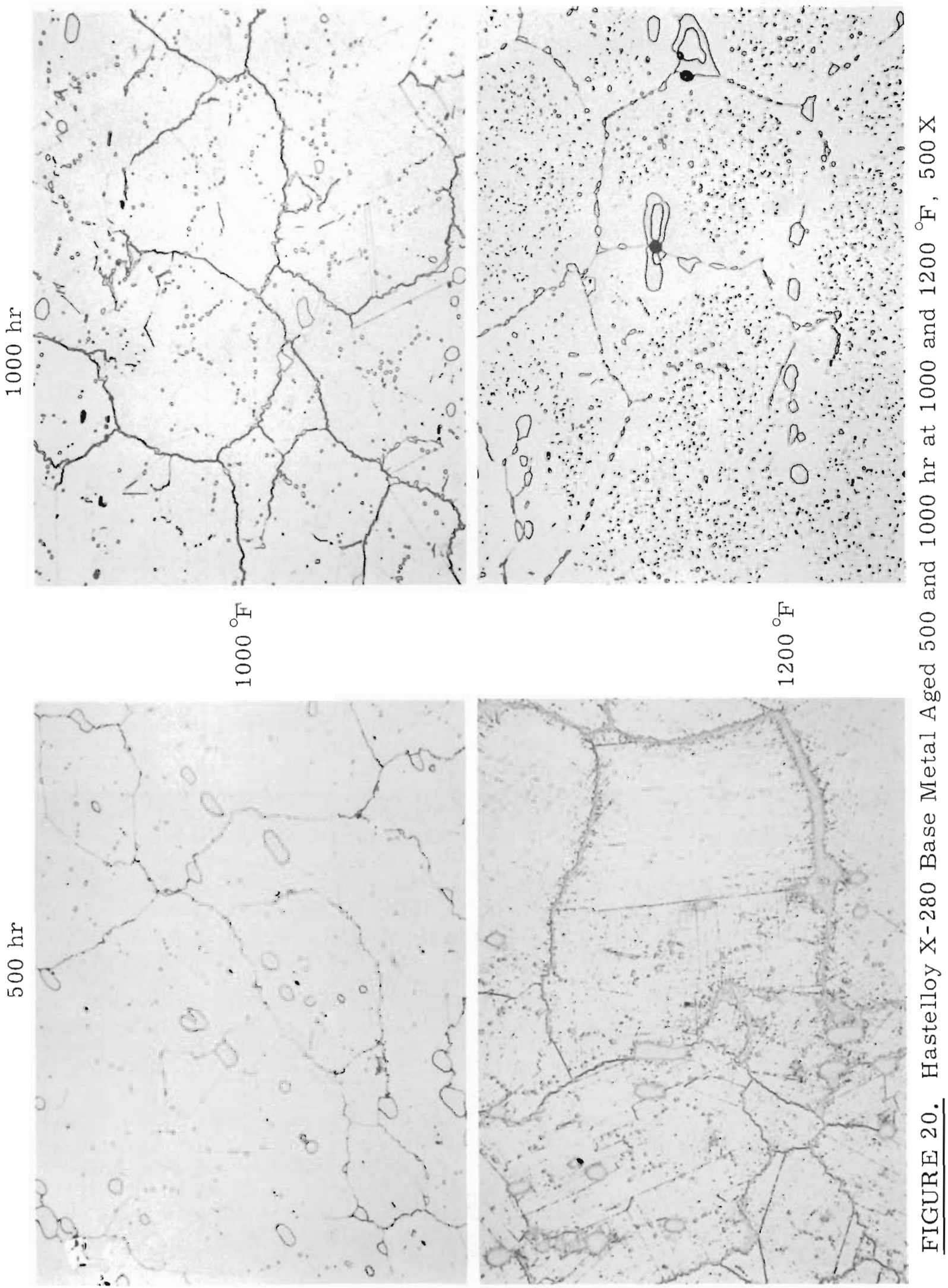




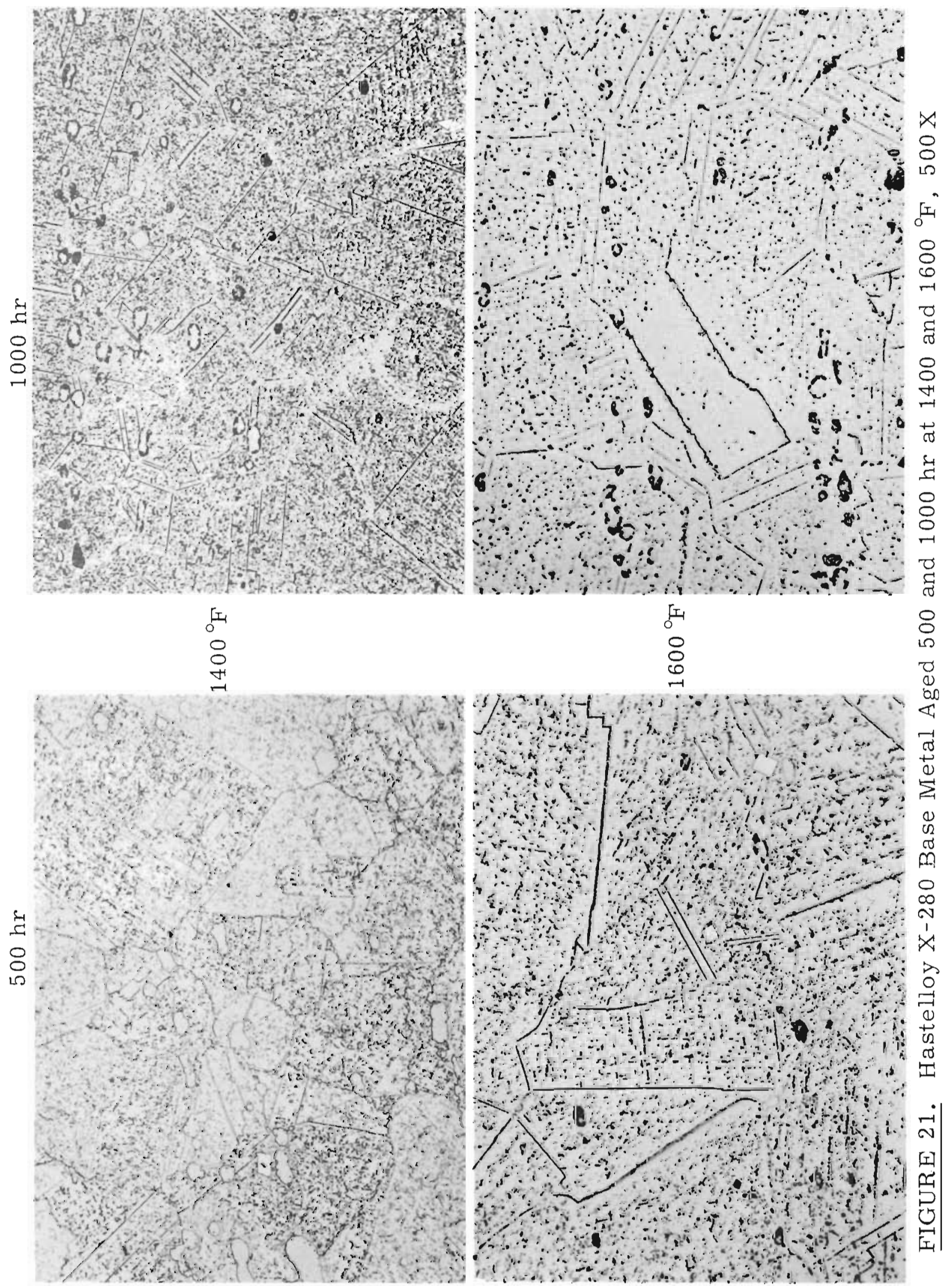



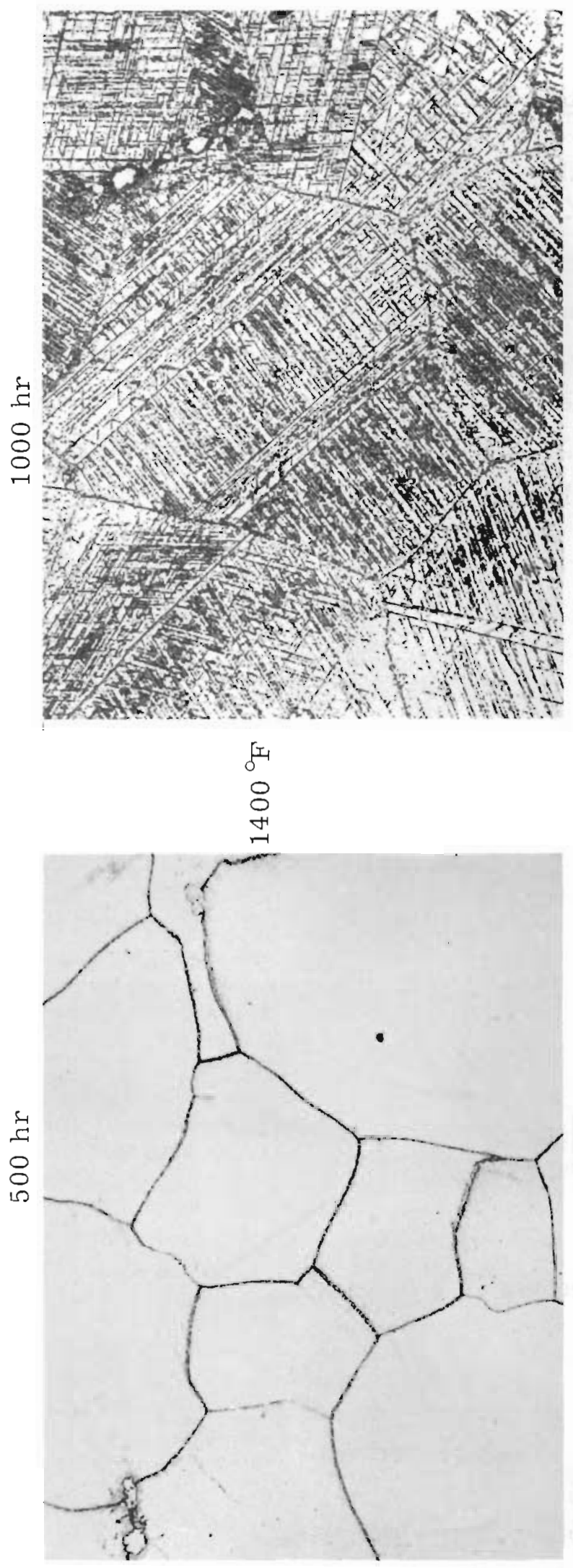

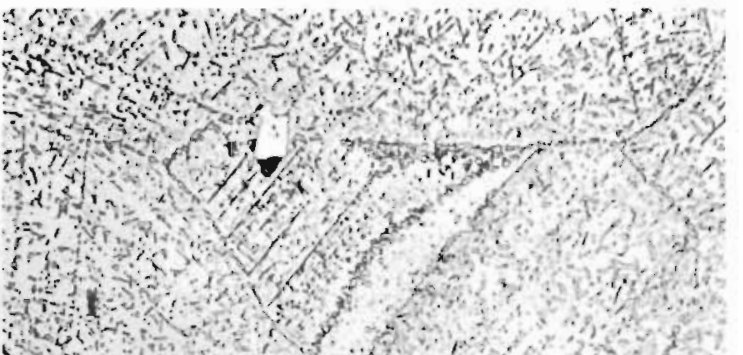

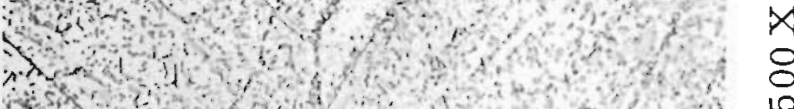
Hentand in

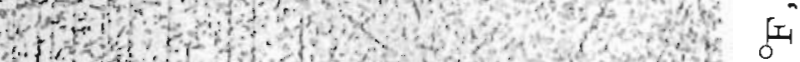
then 1)

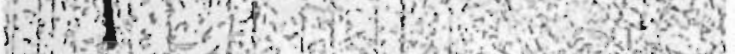

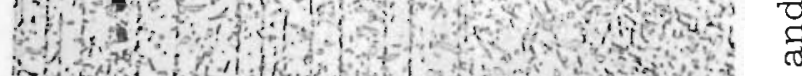
dind

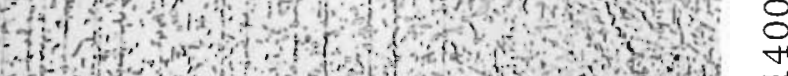

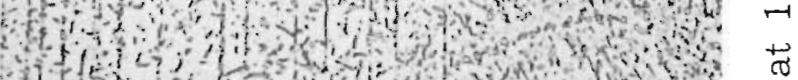
110 of

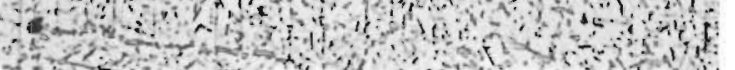
II
8
8
0

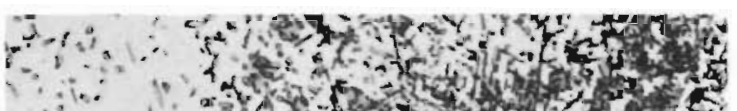
- 1.0 and

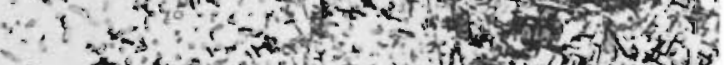
- 40 in sint

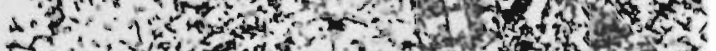

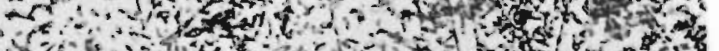

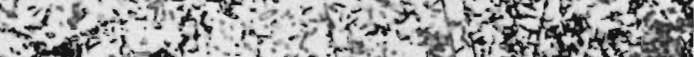

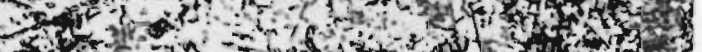

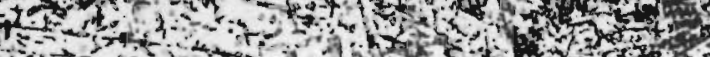

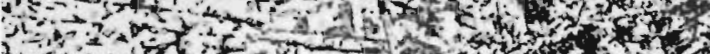

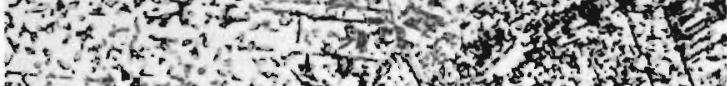

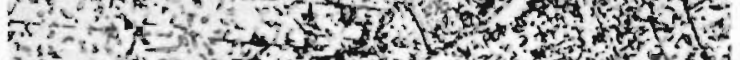

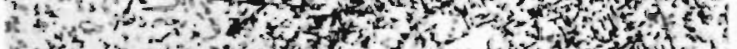

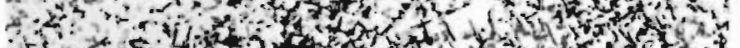

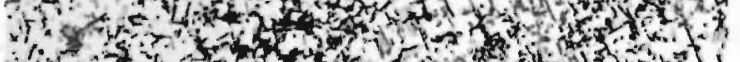

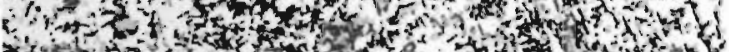

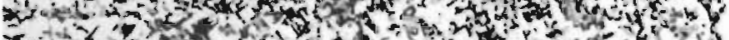

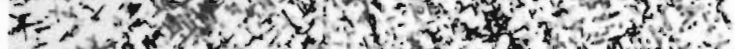

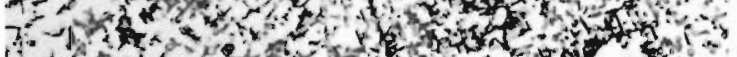
H.

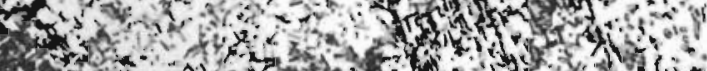

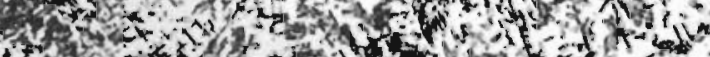

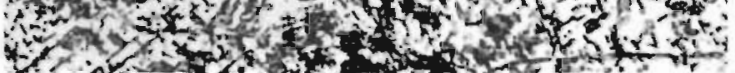




\section{EXPERIMENTAL}

The weld specimens used in this program were intended to simulate field-welded, thick-wall, dissimilar-metal pipe joints. The major steps in the testing program are schematically illustrated in Figure 23. The materials used include Hastelloy $X$ and Hastelloy $W$ weld filler wires, and Haynes 25, 316 SS, and Hastelloy X-280 plates. The chemical analysis of these materials are listed in Table $I$. The weld specimens represent dissimilar metal joints of Hastelloy X-280 to Haynes 25 and Hastelloy $\mathrm{X}-280$ to $316 \mathrm{SS}$, welded with either Hastelloy $\mathrm{X}$ or Hastelloy $\mathrm{W}$ filler wire.

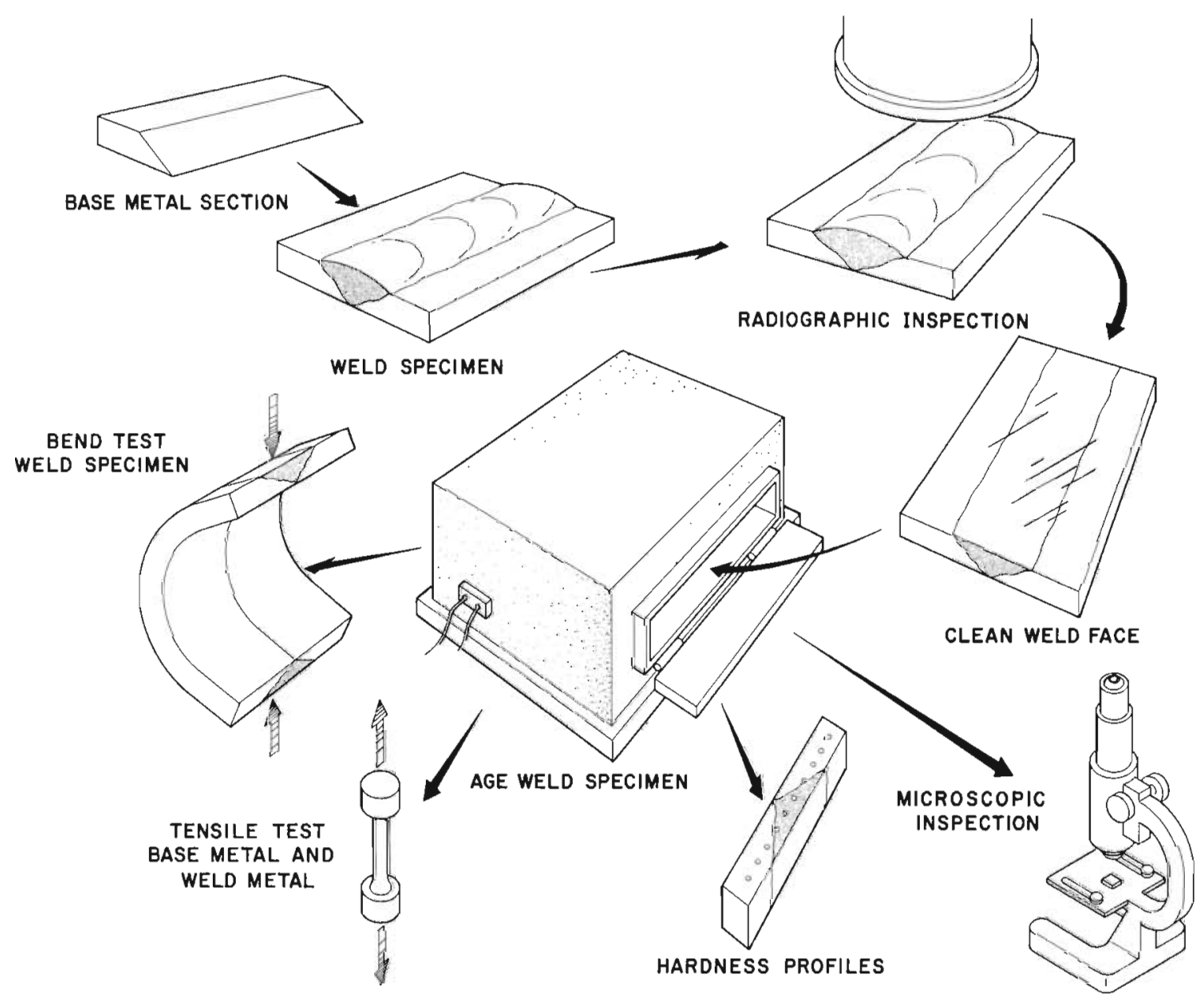

FIGURE 23. The Major Steps in the Testing Program 
The Hastelloy X-280 and Haynes 25 plates were solution heat treated, according to the manufacturer's recommendations, before specimens were prepared for welding. The base metal sections of the weld specimens were made from 0.56 in, thick plate and machined to the dimensions shown ir Figure 24a. Two base metal sections were joined, by the tungste-electrode inert gas (TIG) welding process, to form weld specimens of the dimensions shown in Figure 24b. A total of 60 weld specimens were made for this program. Hastelloy $X$ and Hastelloy $W$ weld filler wires $\frac{3}{32}$ in. in diameter were used. The welding procedure minimized heating to the extent consistent with full penetration, and the specimens were cooled to room temperature between passes. Each specimen required six 9.5 in. long welding passes。 During welding, the base metal sections were ingtiy clamped so that the finished weld specimen was reasonably flat. Extreme warping of the weld specimen would have occurred without this clamping. The residual stresses caused by the welding and the clamping should be representative of field welded joints in the ATR gas loop. Each weld specimen was radiographically inspected according to Section VIII of the ASME boiler and pressure vessel code for unfired pressure vessels. All but 2 of the 60 weld specimens successfully passed the code inspection. The two specimens that did not meet the specifications failed due to lack of penetration and/or lack of fusion. All 60 specimens were included in the testing program, and subsequent destructive tests were carefully watched to see if failure occurred at the defects indicated by the radiographic inspection. In all cases specimen failure was not caused by defects that failed to meet the radiographic inspection specifications. After the inspection, the weld face side of the specimens was machined flat to a number 16 or better finish.

The weld specimens were aged in an inert atmosphere at temperatures of 1000, 1200, 1400, and $1600^{\circ} \mathrm{F}$. The specimens were placed in metal boxes ard the boxes were welded shut. Each box was equipped with three thermocouple entry ports, a gas inlet, and a gas outlet. The boxes were placed inside a furnace, specially built for this program, and the furnace temperature was controlled by a thermccouple measuring the temperature in the

The welding was done by Technical Welding Specialists. 


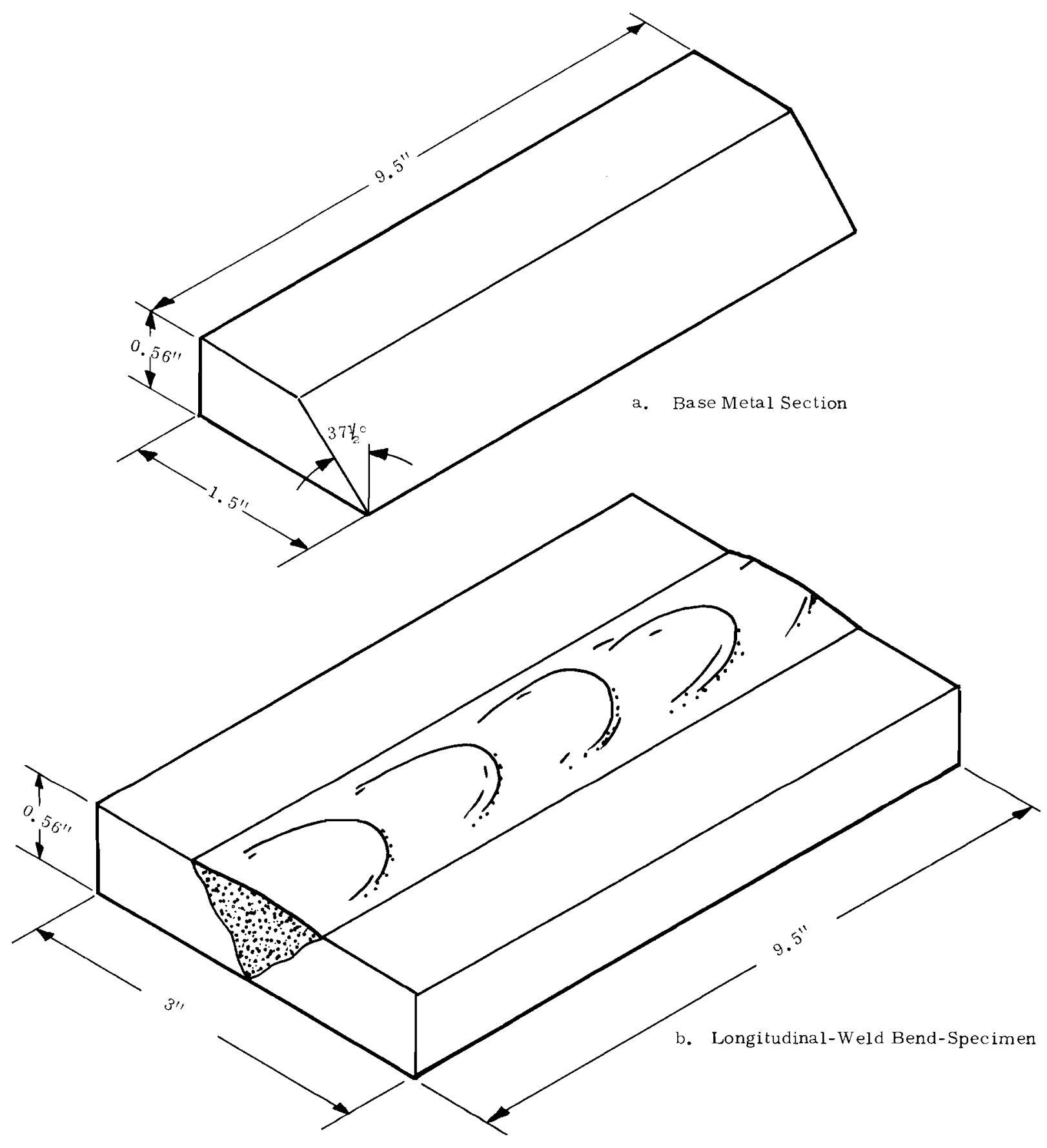

FIGURE 24. Dimensions of Base Metal Sections and Longitudinal Weld Bend-Specimens 
center of the box. Two other thermocouples, measuring temperature at opposite ends of the box, were used to periodically check the temperature gradient in the box. The furnaces were completely surrounded by 4 in. of insulation, and the temperature at any point in the box was within $\pm 10{ }^{\circ} \mathrm{F}$ of the control thermocouple temperature. The inert atmosphere in each of the boxes was maintained by a slow purge of argon. Although bottled argon does have a significant impurity content, the weld specimens maintained a relatively clean surface finish throughout the aging. To remove specimens from the furnace, the boxes were cut open, the specimens removed, and the boxes resealed by welding.

The aged weld specimens were bend tested to determine the relative ductility of the welded joints. The bend test was a longitudinal-weld free bend of the entire weld specimen, with the weld-face being deformed in tension (Figure 23). A grid of 0.25 in. squares was inked on the weld-face side of the specimens, and this grid was used to measure the outer fiber elongation of the specimens after being bent to failure. Failure was designated as the point where an open defect of $0.125 \mathrm{in}$. or greater, in any dimension, occurred on the weld-face of the bend specimen. The weld specimens were given an initial bend of 10 to 15 degrees and then a free bend to failure. The initial bend and free bend devices are illustrated in Figure 25. The elongation of a joint or weld specimen was measured as the maximum elongation in $0.25 \mathrm{in}$. of the outer fibers of the material where failure originated. This bend test is a qualitative measure of the welded joints ductility.

Uniaxial tensile specimens of all base-metal and all weld-metal were made from the ends of the bend specimens. The tensile specimen dimensions are shown in Figure 26. It was possible to obtain two all weldmetal and eight all base-metal tensile specimens from each bend specimen. The material used to make these tensile specimens was relatively undisturbed by the bend test. The tensile specimens were tested on a Instron testing machine at a cross-head speed of $0.005 \mathrm{in} . / \mathrm{min}$. The base-metal tensile specimens that were tensile tested did not contain any weld heataffected-zone material. 

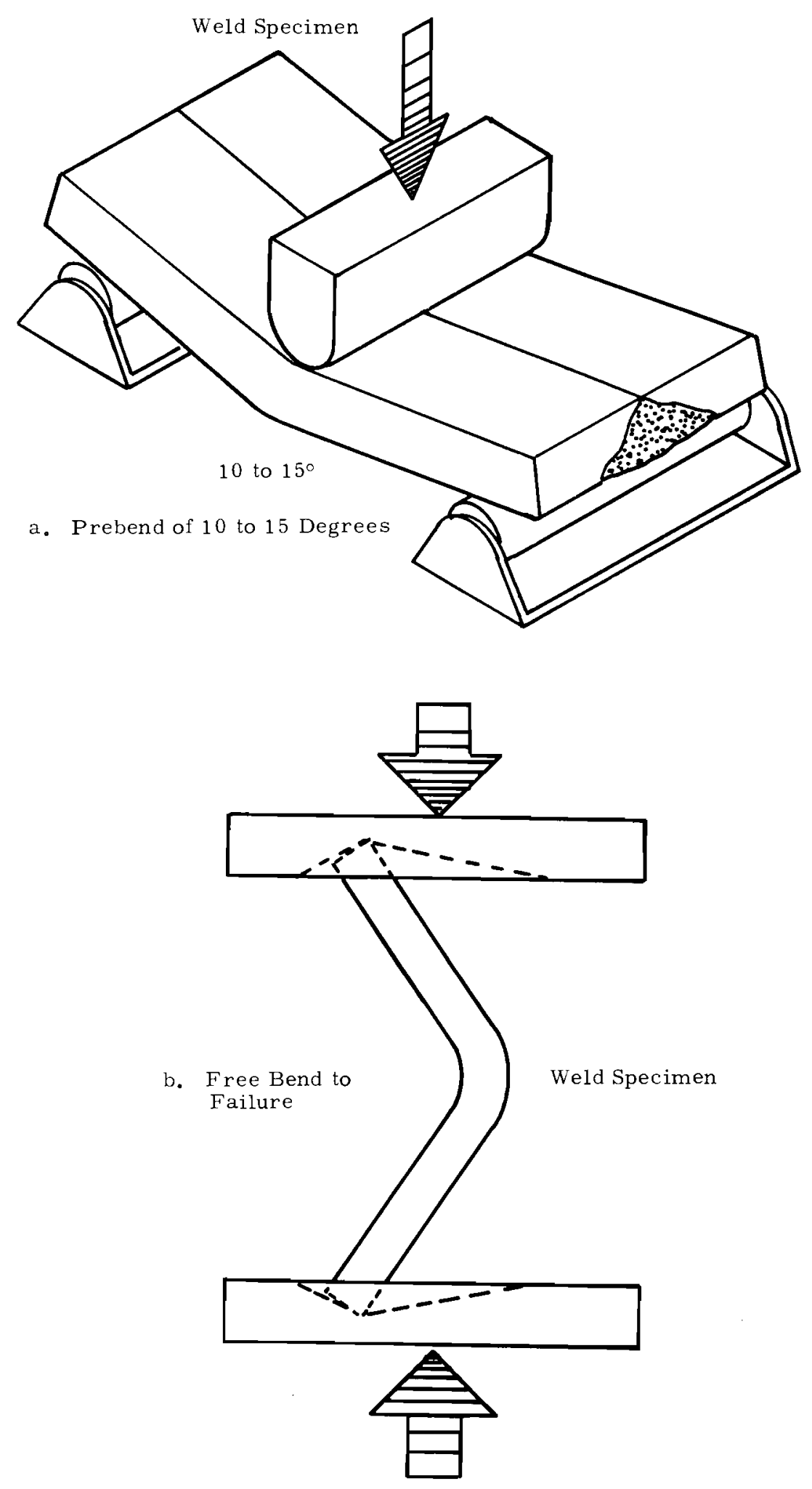

FIGURE 25. Schematic Illustration of Bend Test 


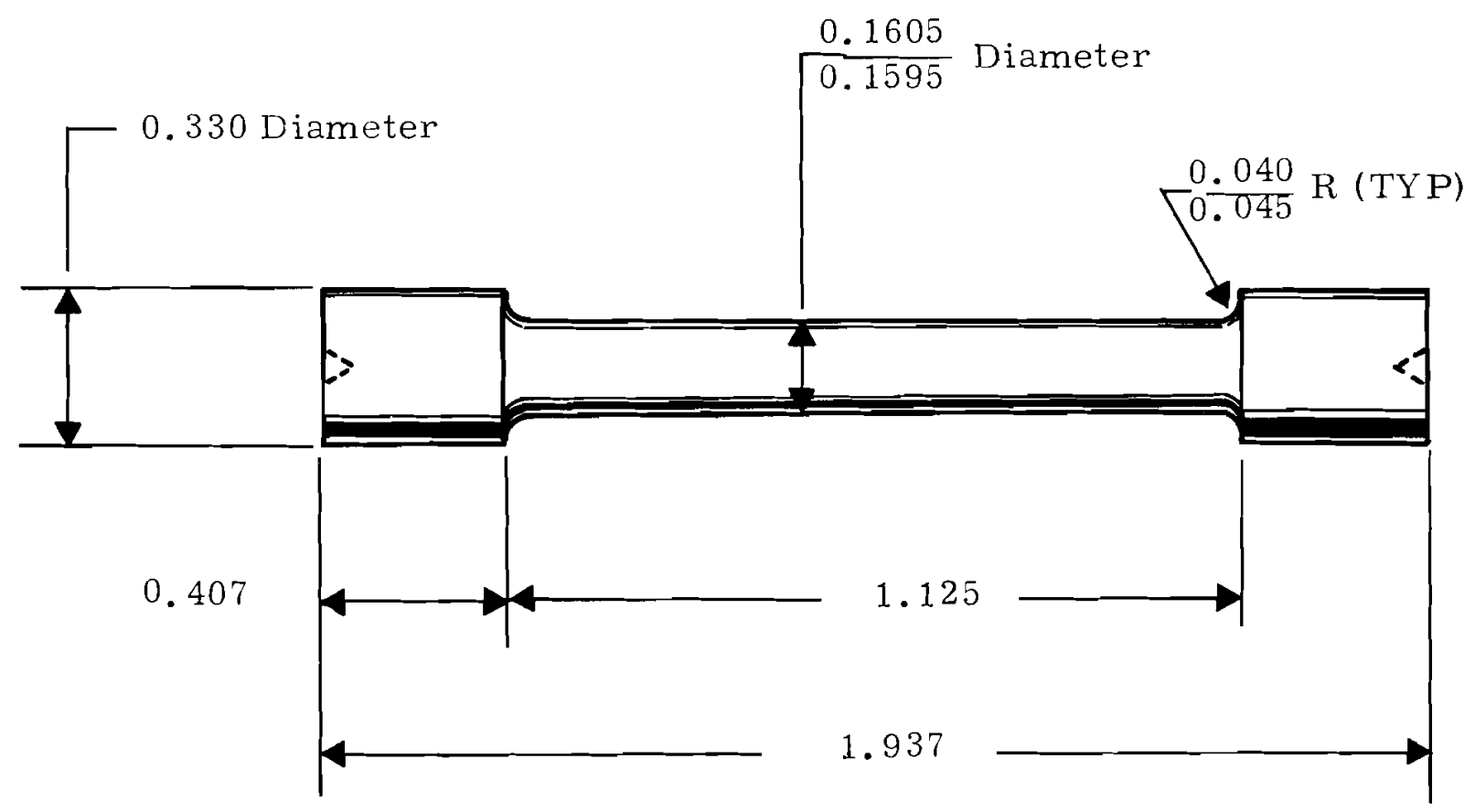

Tensile Specimen

FIGURE 26. Dimensions of Tensile Test Specimens, in.

Hardness profiles of the welded joints were also obtained from samples of the bend specimens. The relative orientation of these hardness profiles is indicated in Figure 23. The hardness was measured on a standard Rockwell hardness tester, and the hardness numbers were converted to Vickers hardness numbers for representation in this report.

All data points presented in this report are the average of tests on two weld specimens. The bend test ductility was determined by two separate bend tests on two weld specimens of the same joint materials and aging treatment. Two tensile specimens, each obtained from a different weld specimen, were used to determine each of the tensile test data points. Two hardness profile specimens, each obtained from a different weld specimen, were used to determine the hardness profile for a given joint material combination and aging treatment. 
The preparation of samples for metallographic examination was difficult. The difficulty was caused by the difference in etching behavior of the aged material. In general each material required a different etchant for each of the material's aging treatments. 


\section{REFERENCES}

1. R. M. Evans. Joining of Nickel-Base Alloys, DMIC-181. (Battelle Memorial Institute of Defense Metals Information Center, Columbus, Ohio). December 20, 1962.

2. J. Wagner and A. M. Hall. The Physical Metallurgy of Cobalt-Base Superalloys, DMIC-171. (Battelle Memorial Institute of Defense Metals Information Center, Columbus, Ohio). July 6, 1962.

3. C. H. Lund. Physical Metallurgy of Nickel-Base Superalloys, DMIC153. (Battelle Memorial Institute of Defense Metals Information Center, Columbus, Ohio). May 5, 1963.

4. R. L. Knecht. Dissimilar Metal Welds of Certain Superalloys and Stainless Steels, HW-78574. (Hanford Laboratories of General Electric Co., Richland, Washington). August 1963.

5. S. T. Wlodek. "Embrittlement of a Co-Cr-W (L-605) Alloy," Transactions of the ASM, vol. 56, p. 287, 1963.

6. G. M. Slaughter. P. Patriarca and R. E. Clausing. "Welding of Nickel-Molybdenum Alloys, "Welding Research Supplement. p. 393 , October 1959.

7. C. R. Kennedy and D. A. Douglas, High-Temperature Mechanical Properties of Hastelloy B and Hastelloy W, ORNL-2402. Union Carbide Corporation, ORNL, Oak Ridge, Tennessee..

8. F. A. Comprelli and U. E. Wolff. Stability of High-Nickel Alloys In Superheated Steam, GEAP-4745. TVollecitos A tomic Laboratory General Electric Company, San Jose, California). November 1964.

9. E. L. Wagoner. Physical Metallurgy and Mechanical Properties of Hastelloy Alloy X, Haynes Stellite Publication. June 23, 1961 .

10. F. H. Ellinger. "The Nickel-Molybdenum System," Transactions of ASM, vol. 30, p. 607, 1942.

11. C. H. Lund and H. J. Wagner. Identification of Microconstituents In Superalloys, DMIC Memorandum 160. (Battelle Memorial Institute of Defense Metals Information Center, Columbus, Ohio). November 15, 1962.

12. Hastelloy X, Haynes Stellite Company, August 1961. (Catalogue)

13. Haynes Alloy No. 25, Haynes Stellite Company, June 1962. (Catalogue)

14. M. D. Randall, R. E. Monroe, and P. J. Rieppel. Methods of Evaluating Welded Joints, DMIC-165. (Battelle Memorial Institute of Defense Metals Information Center, Columbus, Ohio). December 28, 1961 . 
I 
No. of Copies

349

1

1

1

2

2

2

3

80

\section{DISTRIBUTION}

Division of Technical Information Extension

DUN

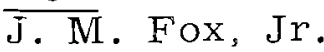

General Electric Company

Building 55-213

Large Steam Turbine

Generator Dept.

Schenectady, N. Y.

C. T. Sims

General Electric Company, Richland

D. H. Curtiss

General Electric Company, San Jose

F.A. Comprelli

C. N. Spalaris

Haynes Stellite Company

701 East Whitler

Whitler, California 90605

F. S. Boericke

Naval Research Laboratory

J.W. Hathorne

L. E. Steele

Richland Operations Office

R. K. Sharp

Technical Information Library

Battelle-Northwest

F. W. Albaugh

R. C. Aungst

J. M. Batch

A. L. Bement

S. H. Bush

J. J. Cadwell

L.J. Defferding

D. R. deHalas

R. F。Dickerson

R.J. Evans

S. L. Faw cett

G. L. Fox

J.C. Fox

M。C. Fraser

H. Harty

$\mathrm{D}$ 。 R. Ireland $(10)$
P. M. Jackson

D. C. Kaulitz (40)

R. L. Knecht

T. E. Michaels

D. P. O'Keefe

P. J. Pankaskie

C. R. Tipton

R. H. Todd

R. G. Wheeler

Technical Information

Files (5)

Technical Publications(2) 


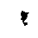

$\bullet$
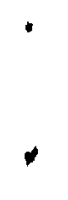

-

. 